Research Article

\title{
Evidence of Southern Ocean influence into the far Northwest Pacific (Northern Emperor Rise) since the Bølling-Allerød warming
}

\author{
Sergey A. Gorbarenko ${ }^{\mathrm{a}, *}$, Xuefa Shi ${ }^{\mathrm{b}, \mathrm{c}}$, Yanguang Liu ${ }^{\mathrm{b}, \mathrm{c}}$, Jianjun Zou ${ }^{\mathrm{b}, \mathrm{c}}$, Olga Yu. Psheneva ${ }^{\mathrm{a}}$, \\ Aleksandr A. Bosin ${ }^{\mathrm{a}}$, Ivan S. Kirichenko ${ }^{\mathrm{d}}$, Antonina V. Artemova ${ }^{\mathrm{a}}$, Elena A. Yanchenko ${ }^{\mathrm{a}}$, \\ Yuriy P. Vasilenko ${ }^{\mathrm{a}}$ \\ ${ }^{a}$ V.I. Ilichev Pacific Oceanological Institute, Far East Branch of the Russian Academy of Sciences, Vladivostok, Russia \\ ${ }^{\mathrm{b}}$ Key Laboratory of Marine Sedimentology and Environmental Geology, First Institute of Oceanography, Ministry of Natural Resources, Qingdao, China \\ ${ }^{\mathrm{c}}$ Laboratory for Marine Geology, Qingdao National Laboratory for Marine Science and Technology, Qingdao, China \\ ${ }^{\mathrm{d}}$ Geology and Mineralogy Institute, Siberian Branch of the Russian Academy of Sciences Novosibirsk, Russia
}

\section{A R T I C L E I N F O}

\section{Keywords:}

Productivity

Sea ice condition

Deep water ventilation

Oxygen and carbon isotope ratio

Stratigraphy

Benthic foraminifera

\begin{abstract}
A B S T R A C T
The role of the Southern Ocean in releasing $\mathrm{CO}_{2}$ (sequestered in the global ocean during the Last Glacial Maximum) into the atmosphere during deglaciation is an important topic for investigation of Earth's climate. Changes in global deep water circulation associated with upwelling of Circumpolar Deep Water (CDW) around Antarctica may have played a part in the $\mathrm{CO}_{2}$ release, but remain poorly studied. The potential response of the Pacific Ocean, including the North Pacific, to upwelling of CDW with its vast reservoir of $\mathrm{CO}_{2}$ remains unresolved. Here we combine productivity proxies, oxygen and carbon isotope values in benthic and planktic foraminifera, data on the occurrence and abundance of ice-rafted debris, and benthic foraminiferal species composition in three sediment cores with published data for three cores from the Northern Emperor Rise for the Last Glacial Maximum, deglaciation and Holocene in order to elucidate the North Pacific role in $\mathrm{CO}_{2}$ redistribution in the past. Age models of the cores are based on radiocarbon data calibrated by ${ }^{14} \mathrm{C}$ atmospheric plateau tuning. The calcium carbonate content in all cores increased abruptly around $14.5 \mathrm{ka}$, indicating an influx of relatively young water enriched in carbonate ion, oxygen and nutrients, and sourced in the Southern Oceans. A decrease in the extent of sea ice at the NER area during early deglaciation is reflected in sharp increases in the productivity of siliceous phytoplankton near the onset of Bølling/Allerød warming, possibly facilitated by the influx of Southern Ocean-sourced nutrient-rich waters.
\end{abstract}

\section{Introduction}

The concentration of carbon dioxide $\left(\mathrm{CO}_{2}\right)$ in the atmosphere is largely determined by the interplay between primary productivity, which regulates the uptake of $\mathrm{CO}_{2}$ into the deep oceanic carbon reservoir (biological carbon pump), and ocean circulation, which determines organic respiration in water and escape of $\mathrm{CO}_{2}$ into the atmosphere (Sigman and Boyle, 2000) The atmospheric $\mathrm{CO}_{2}$ content during the Last Glacial Maximum (LGM, $\sim 23-19 \mathrm{ka}$ ) was $\sim 80 \mathrm{ppmv}$ lower than its preindustrial level, but the exact mechanisms responsible for this change remain elusive. During Heinrich Stadial 1 (HS1, 17.5-14.7 ka), a millennial-scale cold event in the Northern Hemisphere, there was a first pulse in the rise in atmospheric $\mathrm{CO}_{2}$, a drop in atmospheric ${ }^{14} \mathrm{C}$ accompanied by rapid deposition of opal in the Southern Ocean, and a dramatic decrease in the Atlantic Meridional
Overturning Circulation (AMOC) (Anderson et al., 2009; Marchitto et al., 2007; McManus et al., 2004; Monnin et al., 2001). The Southern Ocean may have been a main driver in controlling atmospheric $\mathrm{CO}_{2}$ levels, by accumulating $\mathrm{CO}_{2}$ in the deep oceans during glacials, then releasing it into the atmosphere through upwelling of deep waters around Antarctica during deglaciation (Anderson et al., 2009; Burke and Robinson, 2012; Jansen and Nadeau, 2016; Marshall and Speer, 2012; Sigman et al., 2010). However, the potential mechanisms by which changes in meridional overturning circulation may control ocean-atmosphere $\mathrm{CO}_{2}$ exchange are not clear, and especially the role of the Pacific Ocean, the largest ocean and thus the main reservoir of $\mathrm{CO}_{2}$, is not known (Marshall and Speer, 2012). Paleoceanographers have been studying the subarctic North Pacific extensively during the last decades, because this region is the last link of the global meridional overturning circulation (Du et al., 2018; Galbraith et al., 2007;

\footnotetext{
* Corresponding author.

E-mail address: gorbarenko@poi.dvo.ru (S.A. Gorbarenko).
} 
Gebhardt et al., 2008; Gong et al., 2019; Jaccard et al., 2005; Jaccard and Galbraith, 2013; Keigwin, 1998; Okazaki et al., 2010). Radiocarbon data of paired benthic (BF) and planktic foraminifera (PF), the $\delta^{13} \mathrm{C}$ of $\mathrm{BF}$ and other proxies suggest that North Pacific Intermediate Water (NPIW) was well ventilated during HS1 (Ahagon et al., 2003; Max et al., 2014; Okazaki et al., 2012), while deep oceans remained poorly ventilated (Galbraith et al., 2007; Jaccard and Galbraith, 2013; Max et al., 2014). Deep water ventilation of the western and eastern subarctic Pacific may have been significantly different (Okazaki et al., 2012, 2010). There is considerable evidence for increased deep water ventilation in the northeastern (NE) Pacific during the last deglaciation (Du et al., 2018; Marchitto et al., 2007; Okazaki et al., 2010). A large drop in radiocarbon activity in intermediate waters during HS1 and Younger Dryas (YD, 12.9-11.8 ka), as measured in BF in a core from the continental margin of southern Baja California, requires an injection of old waters from a previously isolated deep-ocean carbon reservoir (Marchitto et al., 2007). Based on changes in neodymium isotope values in a core from the NE Pacific (Gulf of Alaska), Du et al. (2018) inferred that acceleration of NE Pacific abyssal circulation during HS1 was mostly controlled by flushing of Antarctic Bottom Water, triggered by Southern Hemisphere warming and sea ice retreat in the Southern Ocean.

The history of western subarctic Pacific deep ventilation during the last deglaciation is controversial (Galbraith et al., 2007; Gebhardt et al., 2008; Keigwin, 1998; Max et al., 2014; Okazaki et al., 2010). Based on $\mathrm{BF}$ stable isotope data from more than 30 cores from the Northern Emperor Rise (NER) and the Okhotsk Sea from depths of 1000-4000 m, Keigwin (1998) suggested that an intermediate water mass in the far northwestern (NW) Pacific was better ventilated during the LGM than during the Holocene, but deep waters were as nutrient-rich as today. Compiling radiocarbon ages from the NW Pacific, Okazaki et al. (2010) concluded that the average ventilation rate of intermediate-to-deep waters ( 900 to $2800 \mathrm{~m}$ ) during the LGM was $\sim 1500$ years, then decreased to nearly 950 years during HS1, and increased again to $\sim 1550$ years during the Bølling/Allerød (B/A) warming (14.7-12.9 ka). Galbraith et al. (2007) concluded that abrupt and strong NW Pacific deep water ventilation since $14.6 \mathrm{ka}$ was caused by an increase in deep water formation in the North Atlantic, but Jaccard and Galbraith (2013) combined redox-sensitive trace metal data from core PC13 (2393 m depth, NW Pacific; Fig. 1) with previously published data and did not find changes in ventilation at intermediate water depths during the early deglaciation. They suggested that the deepest core showing evidence for enhanced ventilation during HS1 was from $1366 \mathrm{~m}$ water depth, reflecting intensified intermediate water formation. Simulation of North Pacific ventilation by Earth System Modeling shows enhanced intermediate-to-deep ocean stratification due to intensified NPIW formation during HS1, relative to the LGM period (Gong et al., 2019). Increased input of nutrient- and $\mathrm{CO}_{2}$-rich water into this region, caused by wind-driven upwelling within the subpolar North Pacific and the collapse of NPIW formation, may have led to enhanced productivity during the $\mathrm{B} / \mathrm{A}$ warming, based on boron isotope data of PF in a NW Pacific core and climate model simulations (Gray et al., 2018).

Here we present records of several productivity proxies, sea ice influence, $\delta^{18} \mathrm{O}$ and $\delta^{13} \mathrm{C}$ in $\mathrm{BF}$ and $\mathrm{PF}$, redox-sensitive trace metals from six sediment cores from the NER (new data from three cores and previously published data from other three cores) and $\mathrm{BF}$ abundance and species composition for core MD-16 over the last $20 \mathrm{kyr}$. Age models of the sediment cores were based on accelerator mass spectrometry (AMS) ${ }^{14} \mathrm{C}$ dating and robust regional indicators for correlation with the welldated core MD-16 by atmospheric ${ }^{14} \mathrm{C}$ plateau tuning (Sarnthein et al., 2015; Sarnthein, personal communication, 2019). In the results we provide new evidence of environmental evolution and deep water ventilation in the NER area since the LGM with abrupt input of Southern Ocean origin water into the deep water of NER at $14.5 \mathrm{ka}$, near the onset of B/A warming.

\section{Oceanographic setting}

The surface circulation of the subarctic North Pacific is characterized by a large-scale cyclonic pattern of surface currents with two counterclockwise circulating systems: the Alaskan Gyre in the NE Pacific and the Western Subarctic Gyre in the NW Pacific (Fig. 1). Today, the upper waters of the subarctic North Pacific have a strong, permanent halocline because the freshwater input is substantially higher than the evaporation rate. This halocline prevents deep water formation (Emile-Geay et al., 2003; Warren, 1983). The formation of the modern NPIW, a well-defined water mass with high oxygen concentrations, at depths between 300 and $800 \mathrm{~m}$ (Shcherbina et al., 2003; Talley, 1993), is mainly due to physical processes in the Okhotsk Sea, such as brine rejection during the formation of winter sea ice. The modern deep North Pacific water thus has a sluggish ventilation by waters derived from the Southern Ocean and North Atlantic (Kroopnick, 1985; Reid, 1969; Tomczak and Godfrey, 1994). The northward Ekman transport driven by westerly winds in the Southern Ocean upwelled Circumpolar Deep Water (CDW), and one portion of upwelled water moves southward and forms Antarctic Bottom Water (AABW) near the Antarctic coast; another part comes to the north and forms the Subantarctic Mode Water, and denser Antarctic Intermediate Water (AAIW), which may penetrate into the Northern Hemisphere (Anderson et al., 2009). According to Talley's (2003) calculation, today only a small volume of the deep and abyssal water formed as AABW/ Lower CDW in the Southern Ocean and northwardly transported into the Pacific through latitude $32^{\circ} \mathrm{S}$ (with flow nearly equal to $14 \mathrm{~Sv}$ ) continues its northward transport through latitude $24^{\circ} \mathrm{N}$ (at nearly $3 \mathrm{~Sv}$ ), thus making the Deep Pacific Water (DPW) in the North Pacific weakly oxygenated.

Based on the natural $\Delta^{14} \mathrm{C}$ data of Key et al. (2004), Matsumoto (2007) showed two sources of deep water formation in the North Atlantic and around Antarctica and argued for a role of a southern source of deep water formation in the oceans. Using the multi-tracer data set and an overview of WOCE and GEOSECS data, Schlosser et al. (2001) analyzed the main branches of World Ocean circulations, including deep water formation around Antarctica, northward spreading of CDW into the Pacific and bottom water circulation in the Pacific Ocean. They showed that near-bottom $\Delta{ }^{14} \mathrm{C}$ distributions in the GEOSECS and WOCE data allow tracing of the northward flow of CDW into the North Pacific up to the Aleutian Island Arc.

\section{Materials and methods}

\subsection{Core material}

We present new data on three cores, LV63-4-2 (LV63-4), LV76-18-1 (LV76-18) and AV19/4 GC-36 (GC-36), combined with published data from other three cores: RAMA 44PC (R-44), GGC-37 (GC-37) and MD01-2416 (MD-16) (Table 1). Cores LV63-4 and LV76-18 were recovered by a gravity corer on the R/V "Akademik M.A. Lavrentyev" during Russian-Chinese expeditions in 2014 and 2016, respectively. Core GC-36 was recovered by a gravity corer during a Russian-American expedition in 1991, Leg 19/4 on the Russian R/V "Akademik Aleksandr Vinogradov". All cores were collected on the NER, including the Meiji, Detroit and Tenji Seamounts within Pacific Depth Water (PDW) at 2100-3300 m water depths (Fig. 1).

\subsection{Stable oxygen and carbon isotopes}

Shells of the PF Neogloboquadrina pachyderma (Ehrenberg, 1861) sinistral coiling forms (sin.) and the BF Uvigerina auberiana (d'Orbigny, 1839) were picked from $>125 \mu \mathrm{m}$ sediment fractions for stable isotope analysis. Stable isotopes $\left(\delta^{18} \mathrm{O}\right.$ and $\left.\delta^{13} \mathrm{C}\right)$ for core LV63-4 were measured with the Finnigan-MAT 253 mass spectrometer at the State Key Laboratory of Marine Geology, Tongji University, Shanghai (China). 


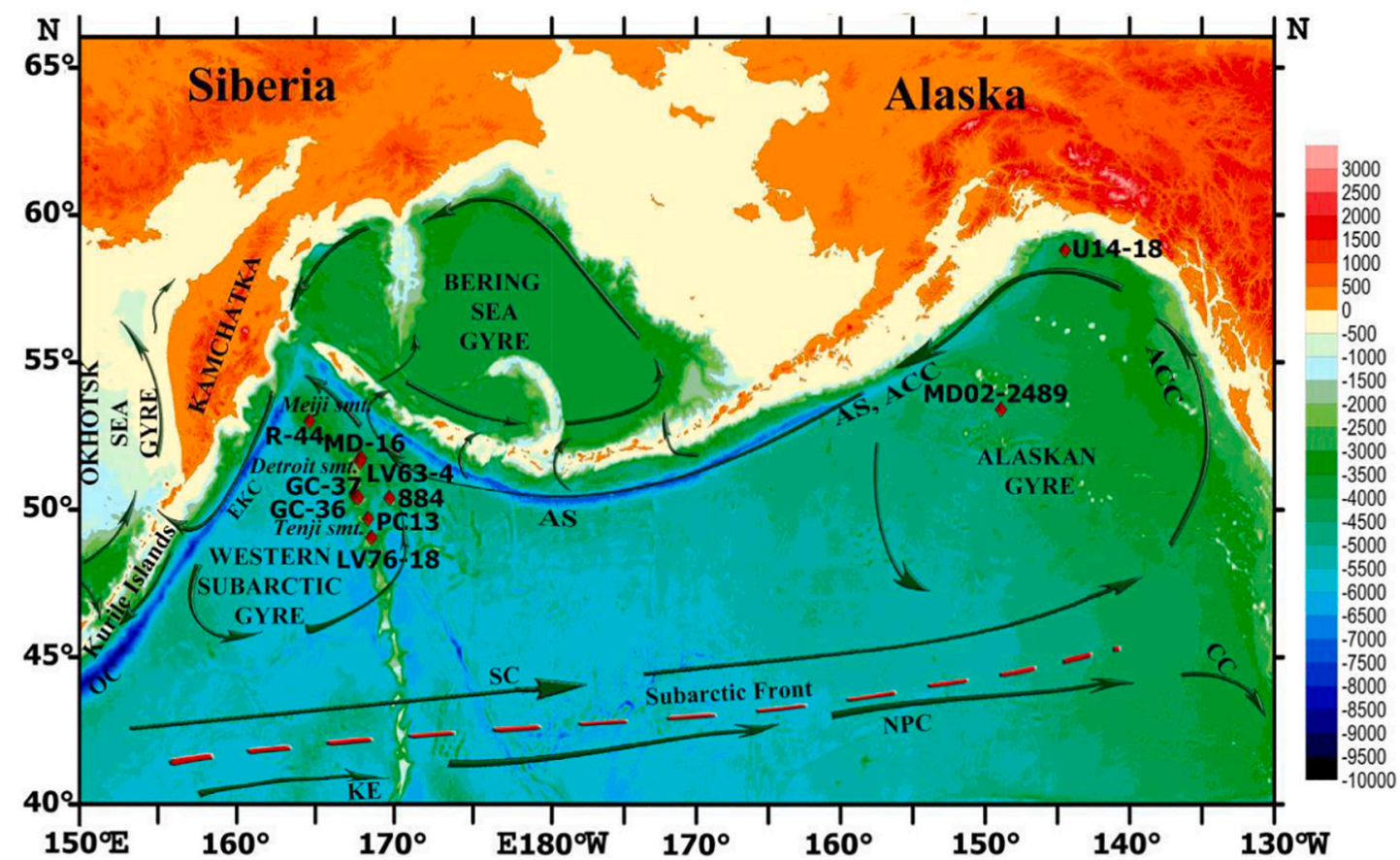

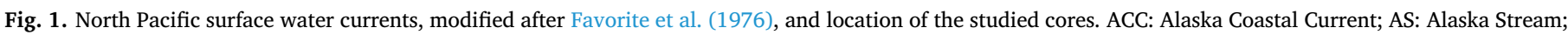
EKC: East Kamchatka Current; OC: Oyashio Current; SC: Subarctic Current; KE: Kuroshio Extension; NPC: North Pacific Current; CC: California Current.

$\delta^{18} \mathrm{O}$ and $\delta^{13} \mathrm{C}$ of the PF and $\mathrm{BF}$ from core LV76-18 were measured with the Finnigan-MAT 253 mass spectrometer at the Far Eastern Geological Institute, Vladivostok (Russia), without preliminary roasting, using a modified method after Velivetskaya et al. (2009). $\delta^{18} \mathrm{O}$ and $\delta^{13} \mathrm{C}$ of the $\mathrm{PF}$ and $\mathrm{BF}$ from core GC-36 were measured with the modified VG mass spectrometer at the laboratory of Dr. L. Keigwin at the Woods Hole Oceanographic Institution, Massachusetts (USA). Isotope results were reported relative to the Vienna Pee Dee Belemnite (VPDB) and calibrated using the NBS19 standard of the National Bureau of Standards. Analytical precision for both $\delta^{18} \mathrm{O}$ and $\delta^{13} \mathrm{C}$ measurement is better than $\pm 0.05 \%$ for cores LV63-4 and LV76-18 and $\pm 0.1 \%$ for core GC36.

\subsection{Radiocarbon dating}

Shells of $N$. pachyderma sin. with a total weight of about 3-8 $\mathrm{mg}$ picked from the $>125 \mu \mathrm{m}$ sediment fraction, were used for AMS ${ }^{14} \mathrm{C}$ dating. Samples from cores LV63-4 and LV76-18 were analyzed at Beta Analytic Inc. (Table 2). Shells of $N$. pachyderma sin. For all samples from cores LV63-4 and LV76-18 were cleaned according to the Beta lab pretreatment protocol. AMS ${ }^{14} \mathrm{C}$ analyses of sample age from core GC36 were carried out at the Center for AMS, Lawrence Livermore National Laboratory, with careful pretreatment cleaning.

\subsection{Productivity proxies}

Calcium carbonate weight $\%\left(\mathrm{CaCO}_{3}\right)$, total organic carbon weight
$\%$ (TOC), the concentration of chlorin, a sedimentary decay product of chlorophyll, and biogenic opal weight $\%$ are considered valuable proxies for paleo-export productivity (e.g., Crusius et al., 2004; Gebhardt et al., 2008; Keigwin, 1998; Keigwin et al., 1992). $\mathrm{CaCO}_{3}$ and TOC concentrations in cores LV63-4, LV76-18 and GC-36 were measured by coulometry using an AN-7529 analyzer at the Pacific Oceanological Institute, Vladivostok (Russia) (Gorbarenko et al., 2004). Biogenic opal content in cores LV63-4, LV76-18 and GC-36 was measured following Mortlock and Froelich (1989), with modification after Gorbarenko et al. (2010), at the Pacific Oceanological Institute, Vladivostok (Russia). Analytical precision for the measurements of $\mathrm{CaCO}_{3}$ and TOC is $\pm 2 \%$ and for biogenic opal is $\pm 5 \%$. The chlorin content in cores LV63-4, LV76-18 and GC-36 was measured using a Cary Eclipse Fluorescence Spectrophotometer following Harris et al. (1996), as modified by Zakharkov et al. (2007). An internal standard sample was measured before and after every batch of samples to control extractions and instrument drift. Precision of the method is about $\pm 2 \%$.

\subsection{X-ray fluorescence analysis}

The elemental composition of sediment core LV76-18, including redox-sensitive metals, was measured at a resolution of $1 \mathrm{~cm}$ by X-ray fluorescence analysis with synchrotron radiation at the Institute of Nuclear Physics, Novosibirsk (Russia), following Piminov et al. (2016). Analytical precision for most element measurements is better than \pm $10-15 \%$. Energy resolution is $160 \mathrm{eV}$ for line $5.9 \mathrm{keV}$.

Table 1

North Pacific sediment cores used in this study, their locations and references.

\begin{tabular}{|c|c|c|c|c|}
\hline Core: full name/short name & Latitude $(\mathrm{N})$ & Longitude (E) & Depth, m & Reference \\
\hline LV63-4-2/LV63-4 & $51^{\circ} 37.8^{\prime}$ & $167^{\circ} 48.6^{\prime}$ & 2946 & This study \\
\hline LV76-18-1/LV76-18 & $49^{\circ} 03.2^{\prime}$ & $168^{\circ} 33.3^{\prime}$ & 2863 & This study \\
\hline AV19/4 GC-36/GC-36 & $50^{\circ} 56.4^{\prime}$ & $168^{\circ} 06.4^{\prime}$ & 3300 & This study \\
\hline MD01-2416/MD-16 & $51^{\circ} 16.1^{\prime}$ & $167^{\circ} 43.5^{\prime}$ & 2317 & Sarnthein et al., 2007; Gebhardt et al., 2008; Sarnthein et al., 2015 \\
\hline RAMA 44PC/R-44 & $53^{\circ} 00.0^{\prime}$ & $164^{\circ} 39.0^{\prime}$ & 2980 & Keigwin et al., 1992 \\
\hline GGC-37/GC-37 & $50^{\circ} 25.2^{\prime}$ & $167^{\circ} 43.9^{\prime}$ & 3300 & Keigwin, 1998 \\
\hline
\end{tabular}


Table 2

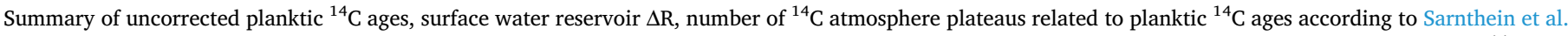

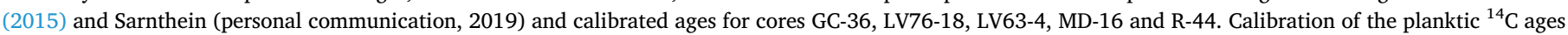
with ages older than $23 \mathrm{ka}$ and younger than $13 \mathrm{ka}$ was performed using CALIB 6.11 (Stuiver and Reimer, 1993).

\begin{tabular}{|c|c|c|c|c|c|c|}
\hline Core depth, cm & Sample name & ${ }^{14} \mathrm{C}$ age, kyr & Error $1 \sigma, \pm \mathrm{yr}$ & $\Delta \mathrm{R}, \mathrm{yr}$ & Plateau no. & Cal. age, kyr \\
\hline \multicolumn{7}{|l|}{ Core GC-36 } \\
\hline 25 & N. pachyderma sin. & 6.86 & 50 & 300 & CALIB 6.11 & 7.06 \\
\hline 49 & N. pachyderma sin. & 10.64 & 70 & 300 & CALIB 6.11 & 11.82 \\
\hline 67 & N. pachyderma sin. & 12.36 & 80 & 170 & CALIB 6.11 & 13.62 \\
\hline 88 & AICC & & & & & 14.50 \\
\hline 102 & N. pachyderma sin. & 14.23 & 70 & & $2 \mathrm{a}$ & 15.70 \\
\hline 125 & N. pachyderma sin. & 15.68 & 70 & & $2 b-3$ & 16.60 \\
\hline 135 & N. pachyderma sin. & 16.53 & 100 & & $3-4$ & 17.70 \\
\hline 155 & N. pachyderma sin. & 17.38 & 90 & & 4 & 18.35 \\
\hline 210 & N. pachyderma sin. & 20.17 & 680 & & 7 & 22.30 \\
\hline 260 & N. pachyderma sin. & 33.68 & 1200 & 1310 & CALIB 6.11 & 36.45 \\
\hline 310 & N. pachyderma sin. & 42.70 & 1200 & 1310 & CALIB 6.11 & 44.60 \\
\hline \multicolumn{7}{|l|}{ Core LV76-18 } \\
\hline 6.5 & N. pachyderma sin. & 6.75 & 30 & 300 & CALIB 6.11 & 6.94 \\
\hline 41 & AICC & & & & & 14.50 \\
\hline 43.5 & N. pachyderma sin. & 13.08 & 97 & & 1 & 14.54 \\
\hline 148.5 & N. pachyderma sin. & 29.78 & 160 & 1310 & CALIB 6.11 & 32.30 \\
\hline \multicolumn{7}{|l|}{ Core LV63-4 } \\
\hline 12 & N. pachyderma sin. & 6.01 & 30 & 300 & CALIB 6.11 & 6.10 \\
\hline 32 & N. pachyderma sin. & 10.08 & 40 & 300 & CALIB 6.11 & 10.98 \\
\hline 54 & N. pachyderma sin. & 12.69 & 50 & & $1 \mathrm{a}$ & 13.80 \\
\hline 60 & AICC & & & & & 14.50 \\
\hline 99 & N. pachyderma sin. & 14.69 & 50 & & $2 \mathrm{a}$ & 15.80 \\
\hline 109 & N. pachyderma sin. & 16.13 & 60 & & 3 & 17.20 \\
\hline 150 & N. pachyderma sin. & 18.95 & 70 & 1310 & $5 b-6 a$ & 20.30 \\
\hline \multicolumn{7}{|l|}{ MD-16 } \\
\hline 16 & N. pachyderma sin. & 6.72 & 30 & 300 & CALIB 6.11 & 6.99 \\
\hline 51 & N. pachyderma sin. & 9.99 & 35 & 300 & CALIB 6.11 & 10.68 \\
\hline 88 & N. pachyderma sin. & 12.69 & 45 & & $1 \mathrm{a}$ & 13.6 \\
\hline 96 & N. pachyderma sin. & 12.56 & 45 & & $1 \mathrm{a}$ & 13.88 \\
\hline 104 & N. pachyderma sin. & 13.09 & 70 & & 1 & 14.15 \\
\hline 117 & AICC & & & & & 14.50 \\
\hline 136 & N. pachyderma sin. & 13.09 & 60 & & 1 & 15.03 \\
\hline 145 & N. pachyderma sin. & 13.92 & & & $2 \mathrm{a}$ & 15.53 \\
\hline 177 & N. pachyderma sin. & 15.38 & 70 & & $2 \mathrm{~b} ?-3$ & 16.40 \\
\hline 199 & N. pachyderma sin. & 16.23 & 90 & & 3 & 17.47 \\
\hline 204 & N. pachyderma sin. & 17.40 & & & 4 & 17.90 \\
\hline 230 & N. pachyderma sin. & 18.00 & & & 4 & 18.83 \\
\hline \multicolumn{7}{|l|}{$\mathrm{R}-44$} \\
\hline 21 & G. bulloides & 6.28 & 70 & 300 & CALIB 6.11 & 6.42 \\
\hline 46 & G. bulloides & 10.13 & 100 & 300 & CALIB 6.11 & 10.80 \\
\hline 71 & G. bulloides & 13.00 & 100 & & 1 & 14.09 \\
\hline 84 & AICC & & & & & 14.50 \\
\hline 121 & Mixed planktic & 14.70 & 100 & & $2 b$ & 16.14 \\
\hline
\end{tabular}

\subsection{Ice-rafted debris}

Abundance of ice-rafted debris (IRD) in core MD-16 was calculated as a percentage of the terrigenous grains counted in an aliquot of the $>150 \mu \mathrm{m}$ fraction of each sample (\% IRD) (Gebhardt et al., 2008). IRD abundance in core R-44 was measured as the number of terrigenous grains per gram of dry bulk sediment in the $>150 \mu \mathrm{m}$ fraction (grain/g sed.) (Keigwin et al., 1992). IRD abundance in core LV63-4 was measured as the weight percentage of the decarbonated and wet-sieved $>$ $150 \mu \mathrm{m}$ sediment fraction (wt $\%$ IRD). IRD in core GC-36 was determined as the number of terrigenous grains in the $>150 \mu \mathrm{m}$ fraction, as counted with a binocular microscope per gram of dry bulk sediment.

We think that the $>150 \mu \mathrm{m}$ fraction mostly contains terrigenous grains, delivered to the studied region by sea ice during seasonal ice melting. Each sieved sample was visually checked using a binocular microscope for possible admixture of volcanic ash and/or other materials. Despite the fact that different approaches were used to determine the IRD, the records show that changes in ice conditions and trends in different cores are comparable.

\subsection{Benthic foraminifera in core $M D-16$}

$\mathrm{BF}$ associations and abundance are mainly controlled by food fluxes to the seafloor and competition for food, while oxygenation of bottom water may be also important under conditions of high organic fluxes (Gooday, 2003; Jorissen et al., 2007; Ohkushi et al., 2000; Thomas et al., 1995). Therefore, BF provide important information about conditions of the sea floor and associated regional paleoceanography (Gooday, 2003; Jorissen et al., 2007). A total of 59 samples, taken every $2-8 \mathrm{~cm}$ in the upper part of core MD-16 $(30-210 \mathrm{~cm})$ in slices $1 \mathrm{~cm}$ thick, were sieved with a $63 \mu \mathrm{m}$-mesh sieve. The $63-250 \mu \mathrm{m}$ fractions were used for $\mathrm{BF}$ analysis. Results of the $\mathrm{BF}$ analysis (total abundance and relative species distribution in assemblages) have been published (Psheneva and Gorbarenko, 2017). Here we provide the total abundance of BF (total number of BF per gram of dry bulk sediment), species richness and the absolute abundance of the dominant species (number of shells per gram of dry bulk sediment). 


\section{Age control}

Age control for the cores is based on AMS ${ }^{14} \mathrm{C}$ data on the PF $N$. pachyderma sin. In order to convert conventional AMS ${ }^{14} \mathrm{C}$ data to calendar years, we used the plateau-tuning technique, i.e., we compared a suite of ${ }^{14} \mathrm{C}$ atmosphere plateaus as recorded in Lake Suigetsu (Sarnthein et al., 2015), where AMS ${ }^{14} \mathrm{C}$ ages of terrestrial macrofossils are placed in a varve-counted age model, thus showing the calendar ages of all ${ }^{14} \mathrm{C}$ atmospheric plateaus (Bronk Ramsey et al., 2012, revised by Schlolaut, 2018). Therefore, tuning of the measured ${ }^{14} \mathrm{C}$ plateaus with the dated ${ }^{14} \mathrm{C}$ atmosphere plateaus provides a chronology for marine sediments (Sarnthein et al., 2015). The age of the abrupt increase of carbonate content (AICC) at a depth of $117 \mathrm{~cm}$ in core MD-16 was accurately defined as $14.5 \pm 0.2 \mathrm{ka}$ according to available AMS ${ }^{14} \mathrm{C}$ data and the last version of plateau tuning for this core (M. Sarnthein, personal communication, 2019) (Fig. 1S). We then applied this age of the AICC to all NER cores, because the environment, hydrology and sedimentation in this region apparently changed synchronously. The age conversion of AMS ${ }^{14} \mathrm{C}$ data of PF for cores LV63-4, LV76-18 and GC-36 to calendar years older than $12 \mathrm{ka}$ in the frame of the dated ${ }^{14} \mathrm{C}$ atmosphere plateaus was provided by plateau tuning similar to that of Sarnthein (personal communication, 2019) (Fig. 1S) (Table 2). Conversion of conventional AMS ${ }^{14} \mathrm{C}$ data for samples with ages younger than $12 \mathrm{ka}$ (off the plateau-tuning time period) was performed using the Marine13 calibration curve of CALIB 6.11 (Table 2). The age models of cores R-44 and MD-16 were modified in the same way, based on the published conventional AMS ${ }^{14} \mathrm{C}$ PF data (Keigwin et al., 1992; Sarnthein et al., 2007) (Table 2). The age model for core GC-37 was accepted as in Keigwin (1998) due to unavailability of the original data set.

\section{Results}

Fig. 2 shows records for productivity proxies (TOC, $\mathrm{CaCO}_{3}$, chlorin, and opal), $\delta^{18} \mathrm{O}$ and $\delta^{13} \mathrm{C}$ of PF and BF, and IRD of the three new cores, compared to published records for cores R-44 and MD-16 versus core depth and versus age for core GC-37 (Gebhardt et al., 2008; Keigwin, 1998; Keigwin et al., 1992). All proxies in all cores show a common pattern of variability over the last $20 \mathrm{kyr}$, consistent with the hypothesis of synchronicity of common environmental and hydrological changes occurring over the whole NER area (Fig. 2). An important common feature in all six cores is the AICC (red line) near the boundary between $\mathrm{HS} 1$ and the B/A warming, consistent with variations of the $\delta^{18} \mathrm{O}$ values of foraminifera. The age of the AICC precisely determined as $14.5 \pm 0.2 \mathrm{ka}$ in the well-dated core MD-16 (red line) is consistent with the modified AMS ${ }^{14} \mathrm{C}$ data of the NER cores (Fig. 2, Table 2). Records of the abovementioned productivity proxies, IRD and $\delta^{13} \mathrm{C}$ of $\mathrm{BF}$ versus age for these NER cores are presented in Fig. 3. As mentioned, the carbonate content in all cores was very low during the LGM and HS1 and increased abruptly near the onset of the B/A warming with subsequent high values. The earlier rise in $\mathrm{CaCO}_{3}$ content for core GC37 may be explained by accepting the original age model of Keigwin (1998). The IRD records show high values during the glacial and early deglacial, a continuous decrease during HS1 and low values after AICC. The pattern of IRD changes demonstrated in the NER area is consistent with the glacial sea ice extension in the North Pacific of Conolly and Ewing (1970), gradual warming of the North Pacific surface water according to Northern Hemisphere summer insolation (Berger et al., 2010) and the modern position of the winter sea ice edge (Reynolds et al., 2002).

The biogenic opal content in all NER cores was very low during the LGM and HS1, rose abruptly during the B/A warming, decreased significantly over the YD and gradually dropped during the Holocene. Such a pattern of regional opal content variability agrees with earlier investigations of the NW Pacific (Gorbarenko, 1996; Jaccard et al., 2005; Keigwin et al., 1992).
Productivity proxies such as the content of chlorin and TOC, responsible for regional production of the photic layer, demonstrate low values during the LGM and a continuous rise since 17.5-16 ka, reaching a maximum at the beginning of the $\mathrm{B} / \mathrm{A}$ warming and gradually decreasing during the B/A warming, YD cooling and Early Holocene. Such changes of these productivity proxies agree with earlier investigations of productivity in the NW Pacific and the Bering Sea (Gebhardt et al., 2008; Kohfeld and Chase, 2011; Riethdorf et al., 2013).

\section{Discussion}

\subsection{A precise age of the AICC as a milestone of NER hydrology}

The PF N. pachyderma sin. and Globigerina bulloides which provided the more significant input into the $\mathrm{CaCO}_{3}$ content of regional sediments mostly dwell and calcify their shells in subsurface water close to the thermocline and surface water, respectively (Bauch et al., 1997; Kiefer et al., 2001; Riethdorf et al., 2013; Simstich et al., 2003). Therefore, their production as heterotrophic organisms is mostly determined by primary and bacterial productivity (Be, 1977). However, accumulation of PF in the sediments of the North Pacific and its marginal seas with the oldest deep water in the World Ocean is also strongly controlled by dissolution of shells in the water column and surface sediments due to shallow depths of carbonate compensation and of the calcite lysocline (Chen et al., 1988; Lyakhin, 1968). The degree of seawater saturation with respect to calcite and aragonite is less than $100 \%$ below a depth of 800-1100 m in most of the NW Pacific and its marginal seas (Chen et al., 1988; Lyakhin, 1968). That is why the carbonate content in the NW Pacific deep sediment is also a good indicator of changes in the regional deep water chemistry. An abrupt increase in $\mathrm{CaCO}_{3}$ content in all NER cores, called the AICC with ages of $14.5 \pm 0.2$ ka near the onset of the $\mathrm{B} / \mathrm{A}$ warming, indicates that the main reason for this change was a sharp improvement of carbonate preservation because the export of regional productivity remained rather high through this boundary according to robust productivity proxies such as TOC and chlorin. Therefore, we argue that the sharp increase in carbonate content was caused by the abrupt influx of relatively young and oxygenated waters, with a high carbonate ion $\left(\mathrm{CO}_{3}{ }^{2-}\right)$ concentration into the regional deep water. Core images and visual lithological descriptions show that sediments in cores LV76-18 and LV63-4 change color from grayish below the AICC to brown-red above it due to a remarkable increase of iron oxidation, confirming strong oxygenation of sediment above this boundary (Fig. 2).

Improved ventilation in the abyssal subarctic Pacific at $\sim 14.6 \mathrm{ka}$ found by Galbraith et al. (2007) has been explained by a linkage to a roughly coeval increase in deep water formation in the North Atlantic. AMOC was nearly, or completely, shut down during the cold HS1, then restarted sharply at the beginning of the B/A warming (14.7 ka) (McManus et al., 2004). However, deep waters formed in the Northern Atlantic take more than 1000 years to travel to the far NW Pacific, so the timing of abrupt changes in NW Pacific deep water chemistry and hydrology as recorded in the NER sediment cores at $14.5 \pm 0.2 \mathrm{ka}$ could not have been caused by North Atlantic circulation changes at $14.7 \mathrm{ka}$. Therefore, we hypothesize that the AICC on the NER was related to an influx of relatively young waters from the Southern Ocean, which occurred during the culmination of Antarctic warming observed in the high-resolution records of the West Antarctica ice core (WDC) at the beginning of the B/A warming (Cuffey et al., 2016; WAIS Divide Project Members, 2013) and related to additional upwelling of CDW (Fig. 4). The distance from origin in the Southern Ocean to the destination on the NER is nearly three times shorter than the distance from North Atlantic areas of deep water formation. Such a scenario is consistent with the penetration of CDW into the North Pacific, as suggested by WOCE and GEOSECS data (Schlosser et al., 2001) and by Schmitz's (1995) synthesis of observational results and assessment of global ocean circulation. 

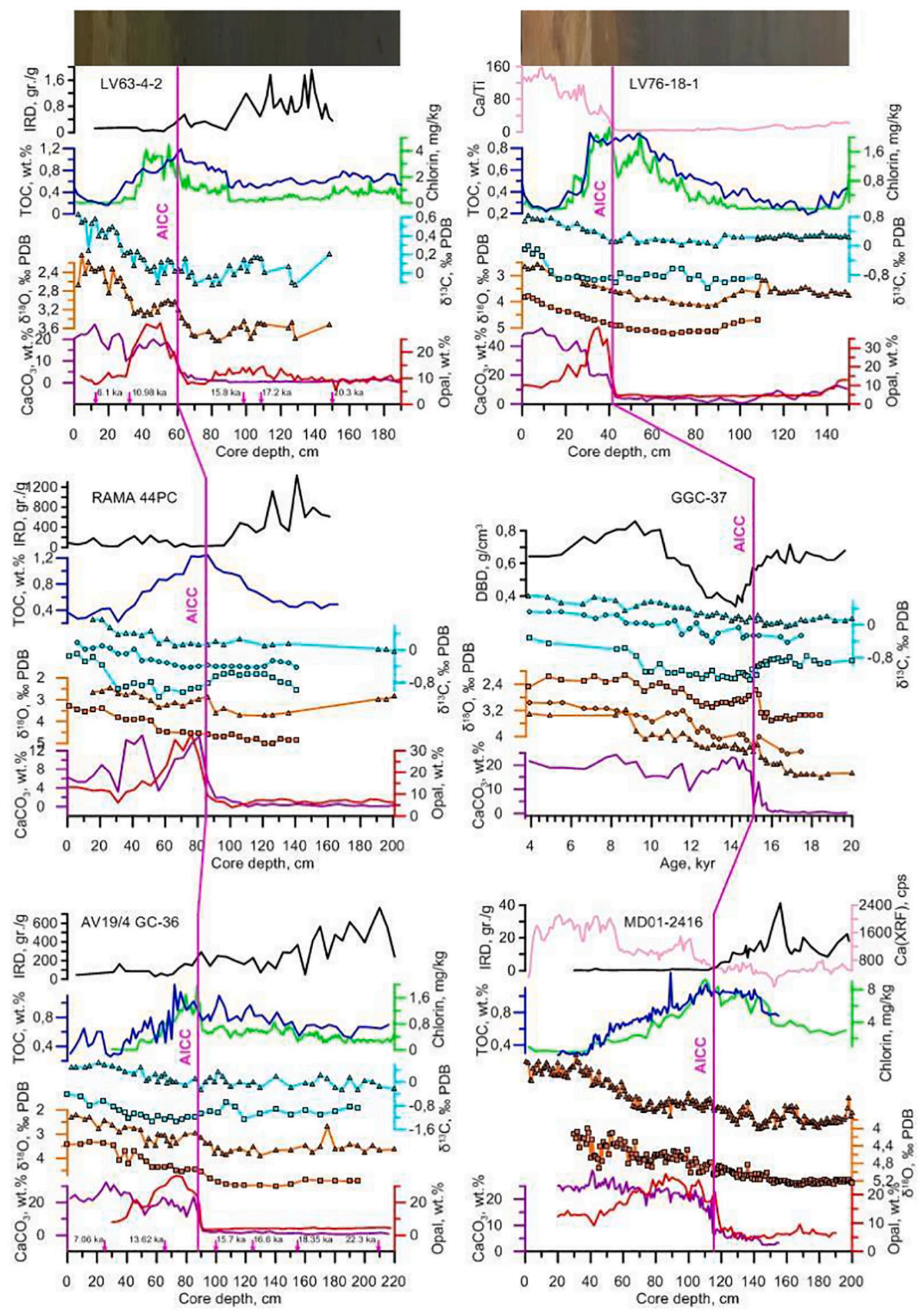

Fig. 2. Records of productivity proxies ( $\mathrm{CaCO}_{3}$, opal, TOC and chlorin content), $\delta^{18} \mathrm{O}$ and $\delta^{13} \mathrm{C}$ of $\mathrm{BF}$ and PF, and IRD content of three new cores (LV63-4, LV76-18, GC-36) and the previously studied cores R-44 and MD-16 versus core depth. Similar proxies for sediment core GC-37 are presented versus age, following Keigwin (1998). The drop in dry bulk density (DBD) after the AICC event in core GC-37 clearly shows a peak of diatom/opal accumulation. Isotope values of $N$. pachyderma sin., Cibicidoides spp. and $U$. auberiana are shown by triangles, circles and squares, respectively. Red lines mark the AICC in all cores. Images of cores LV63-4 and LV76-18 taken onboard are shown at the top. (For interpretation of the references to color in this figure legend, the reader is referred to the web version of this article.) 


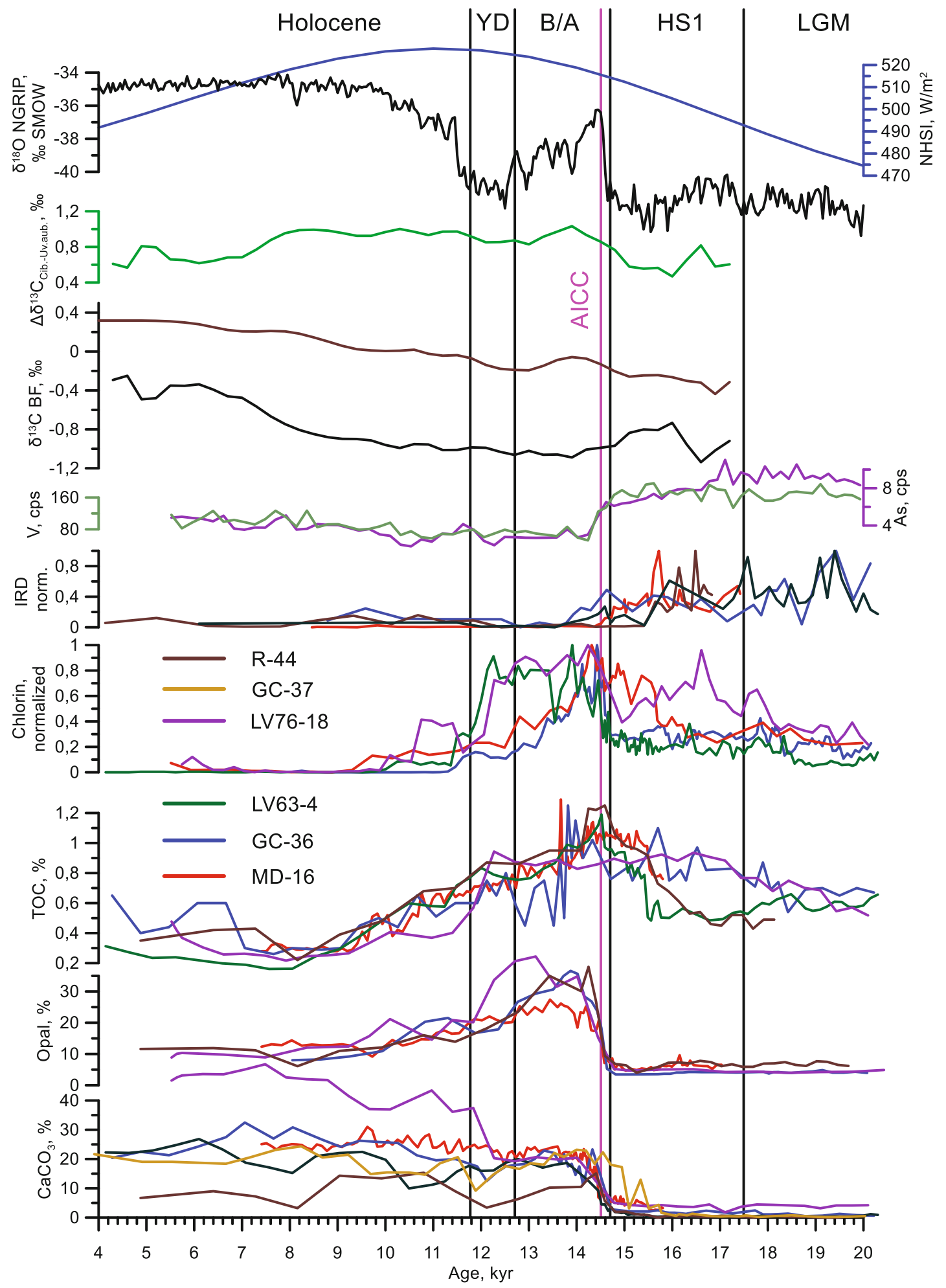

Fig. 3. Temporal changes of productivity proxies $\left(\mathrm{CaCO}_{3}\right.$, opal, TOC and chlorin), IRD content and oxygen and carbon isotopes of $\mathrm{BF}$ and $\mathrm{PF}$ in six sediment cores from the NER area over $20-4 \mathrm{ka} . \delta^{18} \mathrm{O}$ records of the Greenland ice core NGRIP on the GICC05 timescale (EPICA Community Members, 2006) and Northern Hemisphere summer insolation at $65^{\circ} \mathrm{N}$ (Berger, 1978) are shown at the top.

\subsection{Penetration of Southern Ocean water into the NER region}

Temporal changes in proxies for productivity, stable isotope data, IRD records of six NER cores, records of redox-sensitive trace metals for core LV76-18 and the BF dataset for core MD-16, all plotted on revised age models, provide evidence that the Southern Ocean was a source of flushing NER deep water since $14.5 \pm 0.2 \mathrm{ka}$.

\subsubsection{Sea ice cover and primary productivity changes}

The IRD records of cores MD-16, LV63-4, GC-36 and R-44 show that sea ice significantly influenced the NER environment during the glacial period and early deglaciation (Fig. 3). High IRD values in the cores are 

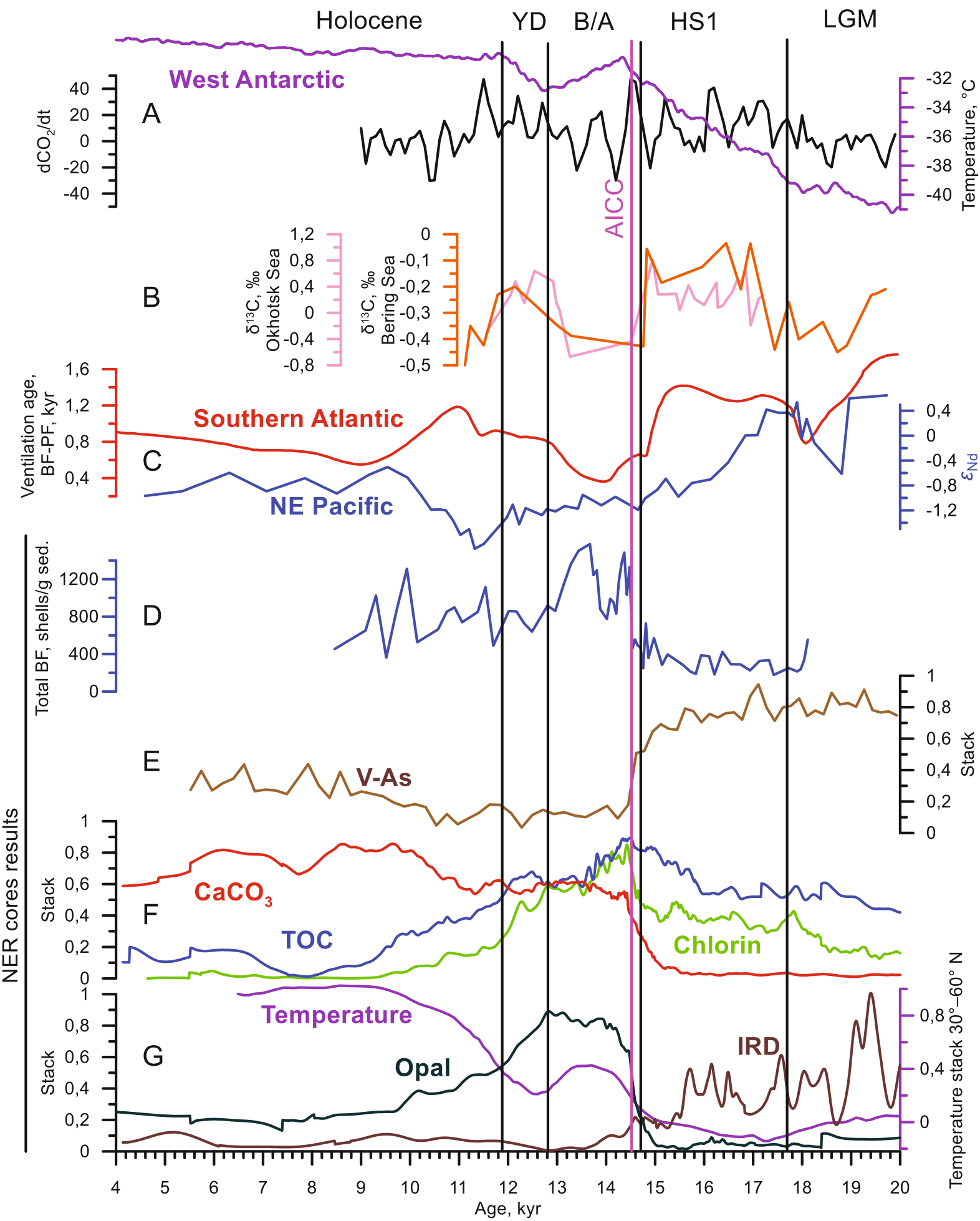

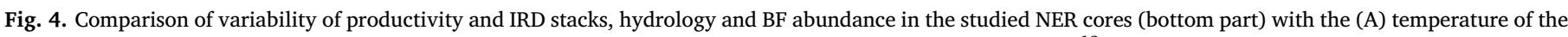
Antarctic (Cuffey et al., 2016) and rate of $\mathrm{CO}_{2}$ releasing into atmosphere $\left(\mathrm{dCO}_{2} / \mathrm{dt}\right.$ ) (Parrenin et al., 2013); (B) $\delta^{13} \mathrm{C}$ of benthic foraminifera, (C) ventilation of deep water in the Southern Atlantic (Skinner et al., 2010) and NE Pacific (Du et al., 2018) over the 20-4 ka period. (D) total BF abundance. (E) stacks of redox-sensitive metals, V and As. (F) stacks of TOC, $\mathrm{CaCO}_{3}$ and chlorin. (G) stacks of opal and IRD plus mean Northern Hemisphere temperature (Shakun et al., 2012). YD: Younger Dryas cooling; B/A: Bølling/Allerød warming; HS1: Heinrich Stadial 1.

consistent with their locations in the NW Pacific zone of "abundant IRD" during glacials, which extended southeast from the Kamchatka Peninsula (Conolly and Ewing, 1970; St. John and Krissek, 1999). VanLaningham et al. (2009) investigated sources of terrigenous Meiji Drift sediments over the last glacial-interglacial cycles using bulk sediment ${ }^{40} \mathrm{Ar}-{ }^{39} \mathrm{Ar}$ and Nd isotopic analyses at ODP Site 884 (Fig. 1). Both proxies agree that during interglacials, the Meiji Drift sediments were largely sourced from relatively young rocks of the Kamchatka Peninsula and Aleutian Arc. However, during glacial periods, these sediments were mostly sourced from older rocks, drained by the Yukon 
River and NE Russia runoff (VanLaningham et al., 2009). Thus a significant part of the glacial NER sediments was delivered by sea ice from the Bering Sea by loading of rocks from the Yukon River and NE Russia rivers into ice during winter formation and its transport into the NW Pacific by surface currents (Mammerickx, 1985). Sea ice thus seems to have a significant influence on the environment of the NER region and suppresses productivity during glacial periods and early deglaciation. During HS1, increased summer insolation led to warming of North Pacific surface waters and decreased the influence of sea ice, promoting longer vegetation seasons and a rise in primary productivity (Figs. 2 and 3). On the other hand, decreased winter insolation led to cooling of surface waters and increasing mixed layer depth, and therefore more active nutrient supply into the photic layer during the winter season. Resumption of AMOC by $\sim 14.7$ ka (McManus et al., 1994) led to the B/ A warming in the North Atlantic, and quickly transferred into the North Pacific and marginal seas by atmospheric teleconnections, facilitating further shrinkage of sea ice influence in the NER region (Gorbarenko, 1996; Hendy et al., 2002; Max et al., 2012) (Figs. 2 and 3).

According to the mentioned sea ice influence and environmental conditions in the NER area, the surface productivity as shown by TOC and chlorin proxies was low during the LGM and early HS1, increased continuously since 17.5-16 ka due to shrinking sea ice cover and amelioration of the surface environment, and reached its maximum values at the beginning of the B/A warming (Figs. 2, 3 and 4). During the B/A warming, YD cooling and Early Holocene, the TOC and chlorin records demonstrate a significant decrease of productivity.

The productivity of diatom algae in the high latitude photic layer is determined by the content of nutrients, especially from dissolved silica, and moderate surface water stratification during the spring bloom season that permit diatom frustules to remain in the photic layer during their 1-2-day reproduction cycle by moderate surface water mixing. Under significant sea ice influence, plentiful spring melting of the sea ice led to freshening of the surface water and an increase of its stratification, suppressing diatom productivity. Such a scenario had occurred in the Okhotsk Sea when there was a strong rise in the productivity of diatoms, and their accumulation had not happened since the $\mathrm{B} / \mathrm{A}$ warming with nutrient-enriched surface water, but only after 6-5 ka when sea ice influence had decreased significantly (Gorbarenko et al., 2014).

A significant decrease in sea ice influence in the NER area since the $\mathrm{B} / \mathrm{A}$ warming was likely the main reason for the rise in the productivity of diatoms and their accumulation in NW Pacific sediments (Fig. 3). The input of nutrient-enriched water by continental runoff associated with intensification of the East Asia monsoon (Wang et al., 2008) and by fluxes of southern origin water likely also stimulated the production and accumulation of diatoms in the North Pacific since the $\mathrm{B} / \mathrm{A}$ warming.

\subsection{2. $\delta^{13} \mathrm{C}$ of benthic foraminifera}

The $\delta^{13} \mathrm{C}$ of BF recorded for NER cores show a sharp decrease of up to $0.3-0.4 \%$ in the $\delta^{13} \mathrm{C}$ of the infaunal foraminifera $U$. auberiana at the onset of the $\mathrm{B} / \mathrm{A}$ warming, in contrast to the gradual increase in the $\delta^{13} \mathrm{C}$ of epifaunal Cibicidoides spp. sampled in core R-44 (Fig. 3). A similar pattern of changes in the $\delta^{13} \mathrm{C}$ of infaunal and epifaunal species around the onset of the B/A warming was found in the NER core GC-37 (Galbraith et al., 2007; Keigwin, 1998). A sharp decrease in the $\delta^{13} \mathrm{C}$ of $U$. auberiana was observed since the onset of $\mathrm{B} / \mathrm{A}$ compared with the change in the $\delta^{13} \mathrm{C}$ of Cibicidoides spp. which was forced by input into the surface sediments of light carbon from organic matter remineralization occurring in surface sediments. Organic matter remineralization led to the release of isotopically light carbon (typically $\sim-21 \% 0$ to $-22 \%$ ) into pore waters, thus more negative $\delta^{13} \mathrm{C}$ values for dissolved inorganic carbon. The difference between the $\delta^{13} \mathrm{C}$ of epifaunal Cibicidoides spp. in core R-44 and the $\delta^{13} \mathrm{C}$ stack of infaunal $U$. auberiana in cores LV76-18, GC-36 and R-44 $\left(\Delta \delta^{13} \mathrm{C}_{\text {epif-inf }}=\delta^{13} \mathrm{C}_{\text {epif }}-\delta^{13} \mathrm{C}_{\text {inf }}\right)$ shows that $\delta^{13} \mathrm{C}$ values in infaunal $\mathrm{BF}$ decreased relative to those in epifaunal species by up to $0.3 \%$, during $14.5-8 \mathrm{ka}$ (Fig. 3).

Hoogakker et al. (2015) argued that the oxygen content in bottom water can be calculated from the carbon isotope gradient within the sediment column. The shift in $\Delta \delta^{13} \mathrm{C}_{\text {epif-inf }}$ in NER sediments $(\sim 0.3 \%)$ since the AICC is related to the increase in oxygenation of the bottom water by up to $\sim 40 \mu \mathrm{mol} / \mathrm{kg}$ according to relationship of Hoogakker et al. (2015). So, $\delta^{13} \mathrm{C}$ data of infaunal and epifaunal foraminifera show an input of relatively young, well-oxygenated waters into the bottom water of the NER from the time of the AICC, close to the onset of the B/ A warming, accompanied by a significant intensification of the remineralization of organic material in sediments.

\subsubsection{Redox-sensitive trace metals}

Another way to estimate changes in deep water ventilation and oxygenation is the variability of the concentration of redox-sensitive trace metals in the sediments. Concentrations of vanadium, rhenium, uranium and arsenic can be used as proxies for suboxic (oxygen-depleted) bottom-pore water conditions (Bodin et al., 2007; Morford and Emerson, 1999). In core LV76-18, V and As show high values across the glacial and early deglaciation, indicating oxygen-depleted conditions and weak deep water ventilation (Fig. 3). Sharp decreases in V and As content since the onset of the AICC clearly indicate a strong increase in deep water oxygenation, due to the influx of oxygenated Southern Ocean waters. $\mathrm{V}$ and As concentrations remained nearly constant up to nearly $10.5 \mathrm{ka}$, then increased slightly, indicating more sluggish ventilation during the Holocene (Fig. 3). The changes in V and As concentrations in core LV76-18 are consistent with the variability in other trace metal proxies for hypoxia, such as the authigenic $U$ in several NW Pacific cores (Jaccard et al., 2010). Therefore, data on redox-sensitive trace metal content show that oxygen-depleted bottom water conditions during the LGM and HS1 were abruptly terminated by the influx of oxygenated waters derived from the Southern Oceans via CDW upwelling at the time of the AICC.

\subsubsection{Benthic foraminifera}

We identified 54 species in the BF assemblages in core MD-16. Small calcareous species such as Alabaminella weddellensis (Earland, 1936) (up to 58\%), Epistominella exigua (Brady, 1884) (up to 60\%), Epistominella arctica Green, 1960 (up to 27\%), Stainforthia spp. (Stainforthia complanata (Egger, 1893) and Stainforthia sp.) (up to 30\%), Cassidulina subglobosa Brady, 1881 (up to 23\%) and Cassidulina norvangi (Thalmann, 1952) (up to $34 \%$ ) dominate in the species assemblages in different periods. The relative abundance of Islandiella norcrossi (Cushman, 1933) was less than $12 \%$, that of $U$. auberiana less than $8 \%$; species of the genus Cibicidoides had a relative abundance of less than $9 \%$, species of the genera Bulimina, Bolivina and Brizalina less than 5-7\%. The absolute abundance of total $\mathrm{BF}$, dominant species and species richness of core MD-16 along with records of TOC, $\mathrm{CaCO}_{3}$, chlorin and opal content of this core are presented in Table $1 \mathrm{~S}$ and Fig. 5. The abundance of the small $(<150 \mu \mathrm{m})$ calcareous species A. weddellensis, E. exigua, E. arctica and Stainforthia spp. is related to the magnitude of seasonal fluxes of organic matter, and represented by opportunistic epifaunal/shallow infaunal phytodetritus species (Gooday, 1988; Gustafsson and Nordberg, 2001; Ohkushi et al., 2000; Polyak et al., 2013; Smart et al., 2019; Thomas et al., 1995).

E. arctica, a species usually smaller than $70 \mu \mathrm{m}$, is one of dominant species in Arctic BF assemblages (Polyak et al., 2013; Wollenburg and Mackensen, 1998). A. weddellensis and E. exigua belong to a group of phytodetritus-feeding species, whose opportunistic behavior is an adaptation to a fluctuating food supply that allows rapid growth and reproduction in the presence of phytodetritus. However, A. weddellensis prefers a better food supply than $E$. exigua (Altenbach et al., 1999; Ohkushi et al., 2018; Takata et al., 2019). Species of the genus Cassidulina have generally been linked to fairly high productivity and a continuous food supply (Mackensen et al., 1995; Ohkushi et al., 2018; Schmiedl et al., 1997). 


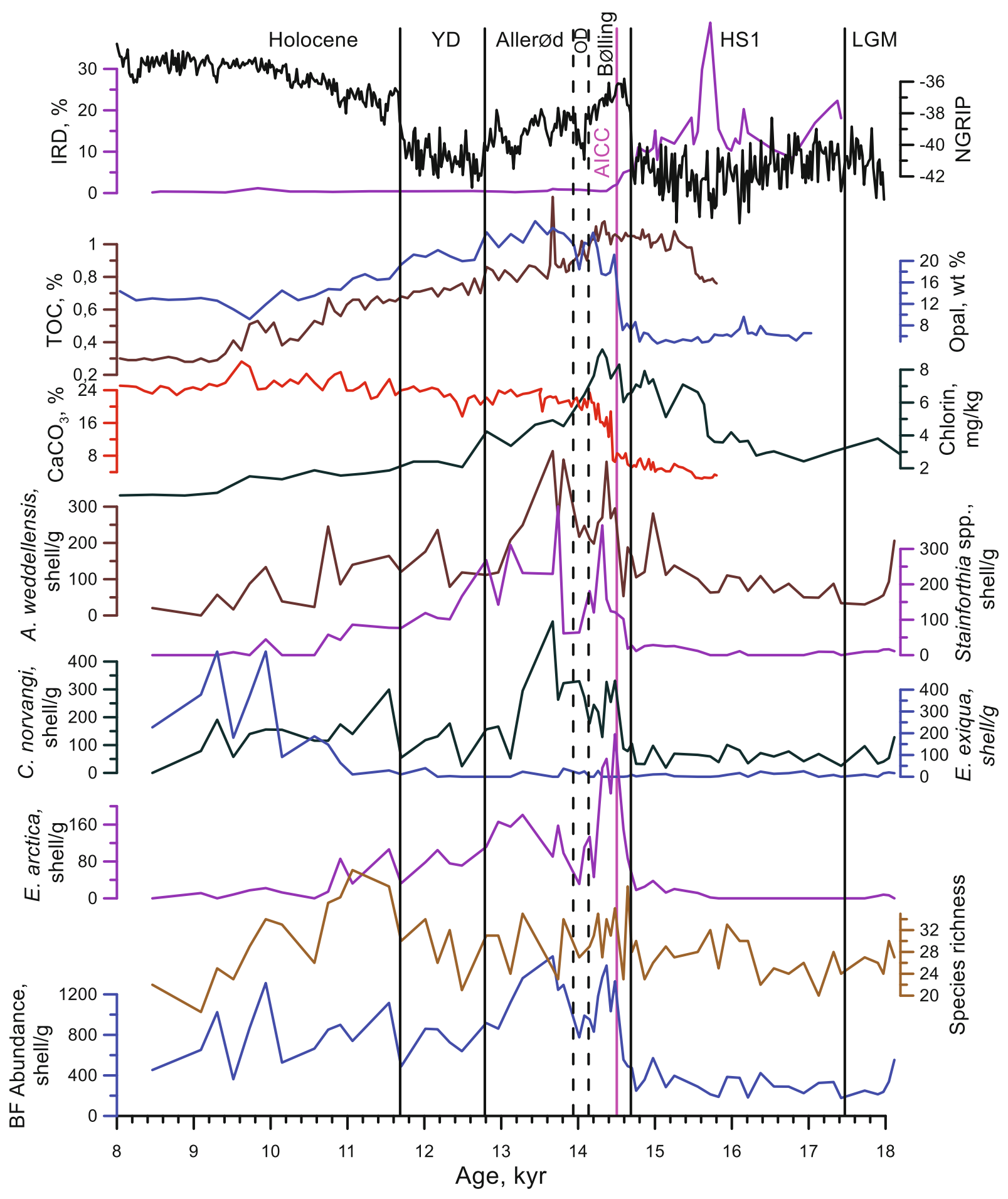

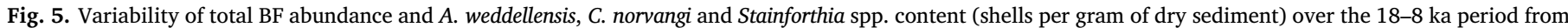

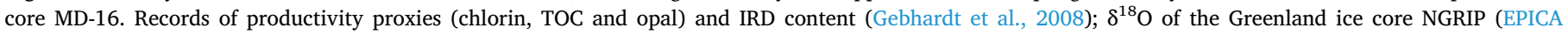
Community Members, 2006) is shown at the top for comparison.

It was shown that the species composition of $\mathrm{BF}$ associations and their abundance are mostly controlled by primary productivity and organic matter fluxes to the seafloor and by bottom water oxygenation when the oxygen concentration is less than $1 \mathrm{~mL} / \mathrm{L}$ (Gooday, 2003; Jorissen et al., 2007; Ohkushi et al., 2000; Thomas et al., 1995). During the LGM and early HS1, the BF abundance was consistently low, in agreement with a low export productivity outlined by TOC and chlorin proxies and significant sea ice influence (Figs. 3 and 5). Because during the glacial period a large amount of atmospheric $\mathrm{CO}_{2}$ was sequestered in the World Ocean through the biological pump and the ventilation of deep water was weak, it is likely that the oxygen concentration in the NER deep water was low, which in turn induced low BF abundance in sediments. A gradual increase of organic fluxes to the sea floor and decrease in sea ice since $\sim 15.6$ ka led to a small rise in $B F$ abundance, mostly by the opportunistic species A. weddellensis (Fig. 5) due to an increase in the seasonal flux of organic matter linked to the slight summer warming. However, a sharp, strong increase in BF abundance occurred at the onset of the AICC (14.5 ka), at which time the total 


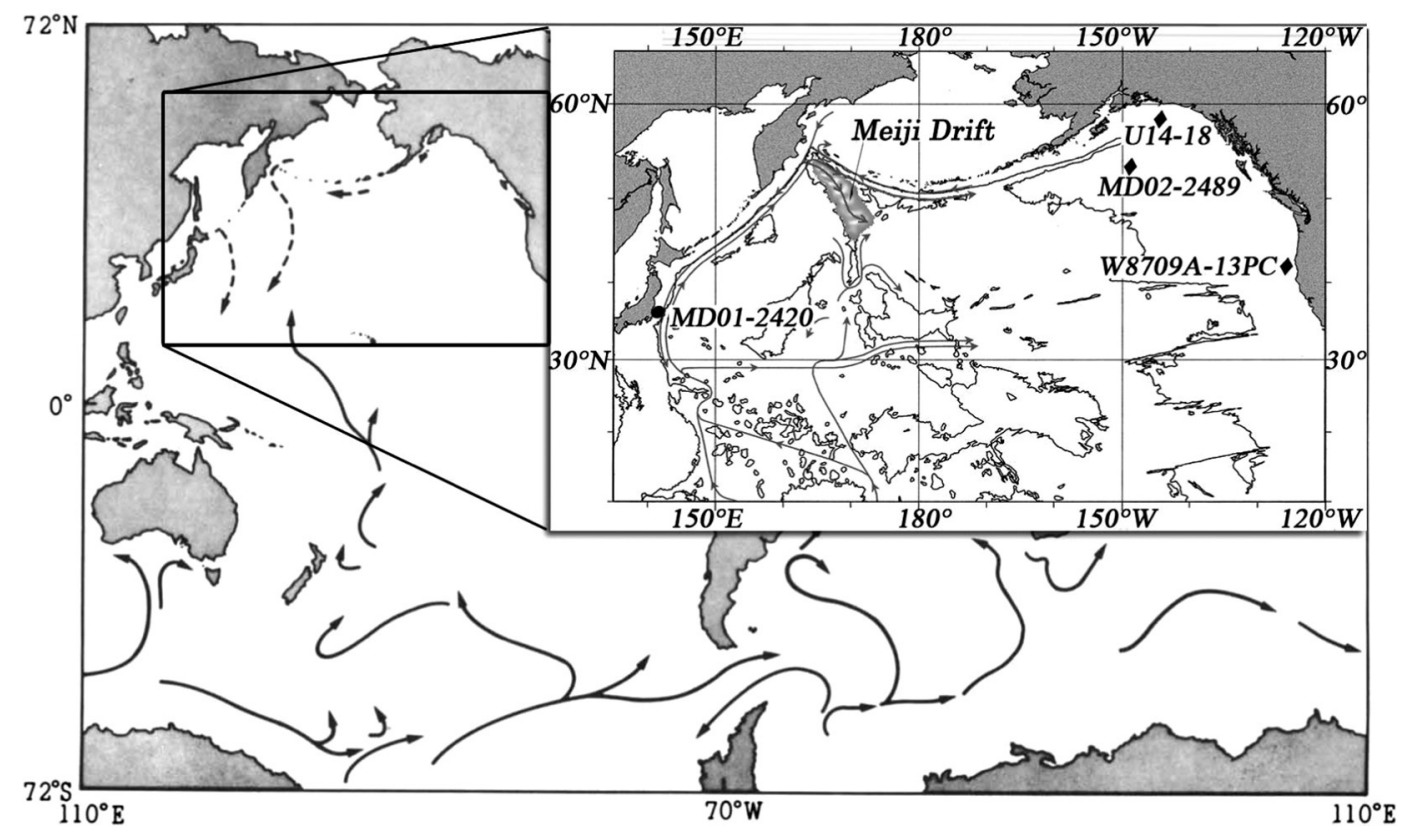

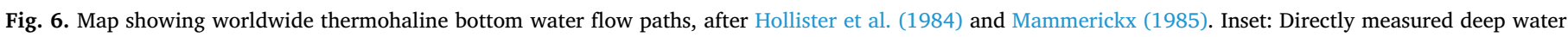
currents in the NW Pacific according to Owens and Warren (2001); Meiji Drift is shown after (Rea, 1995).

organic matter flux was high and did not change significantly according to robust productivity proxies like TOC and chlorin content (Fig. 5).

Therefore, we conclude that the abrupt rise in BF abundance since the AICC was mainly forced by an increase in bottom water oxygenation, another important factor in BF productivity. The small, opportunistic A. weddellensis, E. arctica and Stainforthia spp. had provided the main contribution to $\mathrm{BF}$ assemblages during the Bølling warming. Simultaneously, a large increase in the abundance of $C$. norvangi, dependent on a continuous food supply, indicates significant amelioration of the regional surface water conditions during the Bølling warming. Northern Hemisphere climate cooling of the Older Dryas, characterized by a significant drop in BF abundance in the NER area, indicates that the regional environment became harsher. During most of the subsequent Allerød warming, BF abundance again rose strongly, with a dominant contribution of $C$. norvangi and the opportunistic $A$. weddellensis and Stainforthia spp. Less abundance of another opportunistic species $E$. arctica indicates warmer environmental conditions compared with those of the Bølling warming. The onset of the YD cooling led to a decrease in BF abundance but not to values as low as over the LGM and HS1. With the onset of the Holocene, BF abundance increased slightly, accompanied by a significant rise in species richness, and then gradually decreased. The warmer environment of the Holocene during the period of 10-9 ka was favorable for a remarkable increase in abundance of the opportunistic species E. exigua while annual fluxes prevailed over pulses of fresh phytodetritus (Altenbach et al., 1999; Gooday, 2003). So, data of BF abundance and species composition confirm significant oxygenation of the deep water of the NER area since the AICC, very close to the B/A warming, as a result of the input of Southern Ocean origin water enriched by dissolved oxygen and nutrients.

The results presented for $\mathrm{BF}$ abundance and species composition, combined with the $\delta^{13} \mathrm{C}$ of epifaunal and infaunal $\mathrm{BF}$, allow a correction to be made in the interpretation of the primary and export productivity changes in the NER area during the B/A warming, in contrast to the recorded TOC and chlorin values in light of evidence found for the input of young, oxygenated water in the NER area. As mentioned earlier, the TOC and chlorin stacks demonstrate continuous growth during HS1, maximal values at the onset of the $\mathrm{B} / \mathrm{A}$ warming and a subsequent gradual decrease over the B/A-YD-Early Holocene (Fig. 4). However, the $\delta^{13} \mathrm{C}$ values for epifaunal and infaunal $\mathrm{BF}$ indicate that the difference between the $\delta^{13} \mathrm{C}$ of epifaunal and infaunal foraminifera was significantly increased since the AICC event, signaling an additional input of light carbon in the pore water as a result of the acceleration of organic remineralization. Chlorin, an easily oxidized product of chlorophyll decay, was destroyed faster than the more refractory TOC (Fig. 4). Values of BF abundance over the Allerød warming being a little higher than those at the Bølling warming show that organic fluxes determined by primary and export production in the NER area were rather high and did not change significantly during the B/A warming, consistent with a high supply of nutrients, warm climate and low sea ice influence. Thus, the recorded decrease in TOC and chlorin proxies during the B/A warming was likely biased by accelerated organic remineralization under growth sediment oxygenation since the AICC. The results for productivity changes during the B/A warming in the Okhotsk and Bering Seas, basins which get water from the NW Pacific, confirm this pattern of productivity (Gorbarenko et al., 2004; Seki et al., 2004).

\section{3. $C D W$ upwelling and south-north transit of $A A B W$}

Records of the several productivity proxy stacks $\left(\mathrm{CaCO}_{3}, \mathrm{TOC}\right.$, chlorin, and opal), IRD values for the six NER cores, the $\delta^{13} \mathrm{C}$ offset in epifauna-infauna $\mathrm{BF}$, the content of redox-sensitive trace metals in core LV76-18 and changes in BF abundance in core MD-16 over $20-4$ ka are presented in Fig. 4. According to the obtained results, the influence of sea ice on the surface environment of the NER region was significant during the LGM, decreased over HS1 and became negligible since the onset of the B/A warming consistent with the increase in Northern Hemisphere summer insolation (Berger et al., 2010, Fig. 3) and warming in the mid-latitude of the Northern Hemisphere $\left(30^{\circ}-60^{\circ} \mathrm{N}\right)$ (Shakun et al., 2012). Forced by the mentioned regional and global surface environmental changes, the primary and export productivity in the NER area recorded in the TOC and chlorin proxies has increased continuously since HS1 and reached maximal values at the onset of B/A warming; while the stacks of carbonate and $\mathrm{V}-\mathrm{As}$ content and difference between the $\delta^{13} \mathrm{C}$ of the benthic epifauna and infauna, as well as $\mathrm{BF}$ abundance, proxies responsible for deep water chemistry changes, clearly indicate abrupt flushing by well-oxygenated waters at $14.5 \mathrm{ka}$ (AICC event, close to the start of the B/A warming) into the deep water of the NER area. 
Some published records of hydrology and deep water ventilation changes of the Southern Ocean based on the BF-PF age differences (Skinner et al., 2010) and of the NE Pacific inferred by authigenic neodymium isotope (Du et al., 2018) over the LGM-deglacial-middle Holocene are also shown in the upper part of Fig. 6. The record of the deglacial temperature changes of western Antarctica (Cuffey et al., $2016)$ is based on the highly resolved $\delta^{18} \mathrm{O}$ measurement of the West Antarctic Ice Sheet Divide ice core (WAIS Divide Project Members, 2013), which is more tightly related to the Southern Ocean sea ice condition and CDW upwelling evolution (Fig. 6). The western Antarctica temperature start to increase since nearly $19 \mathrm{ka}$, consistent with the start of $\mathrm{CDW}$ upwelling and release of deep water $\mathrm{CO}_{2}$ into the atmosphere, rise with acceleration at nearly $17.5 \mathrm{ka}$ (onset of HS1) and culminated at nearly 14.5 ka with remarkable warming (Fig. 6). Likely, such culminated peak in Antarctica temperature at the $14.5 \mathrm{ka}$ had induced additional environmental and sea ice changes in the Southern Ocean with resulted strengthening of CDW upwelling and AABW formation which moved northward in the World Ocean and reached the NW Pacific. Acceleration of CDW upwelling at the boundary of HS1/B/ A warming was accompanied by increase of $\mathrm{CO}_{2}$ exhalation into the atmosphere before it was sequestered in the ocean as recorded by remarkable peak in the rate of $\mathrm{CO}_{2}$ releasing into atmosphere $\left(\mathrm{dCO}_{2} / \mathrm{dt}\right)$ (Fig. 4). The model simulations of (Du et al., 2018) show that such a culmination of Antarctic and Southern Ocean environments may increase the formation of AABW up to a factor of 1.7.

In the North Pacific, the records of the $\delta^{13} \mathrm{C}$ of epibenthic foraminifera from cores of the Bering and Okhotsk Seas coupled with radiocarbon-derived ventilation ages show abrupt deepening of NPIW formation up to a water depth of 700-1750 m during cold event HS1 (Fig. 4), forced by increased sea ice formation in the Bering and Okhotsk Seas and decreased surface water stratification due to weaker water vapor transit from the cold North Atlantic (Gorbarenko et al., 2014; Max et al., 2014). So at one hand the hypothesized abrupt input of young southern origin water in the NER deep water at the AICC event (close to the start of the B/A warming) followed by the results for six NER cores was affected by culmination of the Antarctic and Southern Ocean environment amelioration at the boundary of HS1 and B/A warming, acceleration in AABW/Lower CDW formation, enriched by oxygen and nutrients, that improved deep water ventilation in the Southern Ocean and the North Pacific (Fig. 4). On the other hand, significant deepening of NPIW formation during HS1 (Max et al., 2014) led to increasing of the intermediate water density in the NW Pacific, while following drop in NPIW formation at the onset of the B/A warming decreased the weight of the water column above PDW, likely, facilitating the upward movement of the AABW in the NER area. Therefore, variations in intermediate water formation in the North Pacific may serve as additional factor affected the deep water ventilation over the NER area.

Inferred by suite of evidences from the six studied cores, the increase of the deep water ventilation over the NER area around the boundary of HS1 and B/A warming, the deep water ventilation changes in the Atlantic section of the Southern Ocean (Skinner et al., 2010) and deep water ventilation in the NE Pacific (Du et al., 2018) - all these examples indicate the northward expansion of the AABW in the World ocean and the North Pacific (Fig. 4).

Possible pathways of Southern Ocean waters to the NER over the present and past can be evaluated using the publications by Hollister et al. (1984) and Mammerickx (1985) (Fig. 6). Direct measurements of modern deep water currents in the NW Pacific (Owens and Warren, 2001) are consistent with models of abyssal circulation (Hollister et al., 1984), as directed by the sea floor topography, and westward Coriolis forcing of deep water from southern sources. The western branch of deep water currents moves northward along the Japan and Kuril-Kamchatka Trenches, then divides while crossing the Aleutian Trough: one branch flows to the Bering Sea, another one eastward along the Aleutian Trough, and the third flows in a south-southeastern direction
A

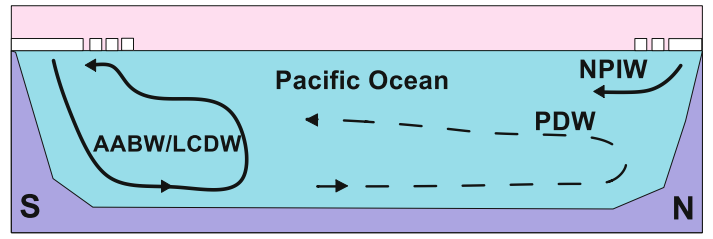

LGM S
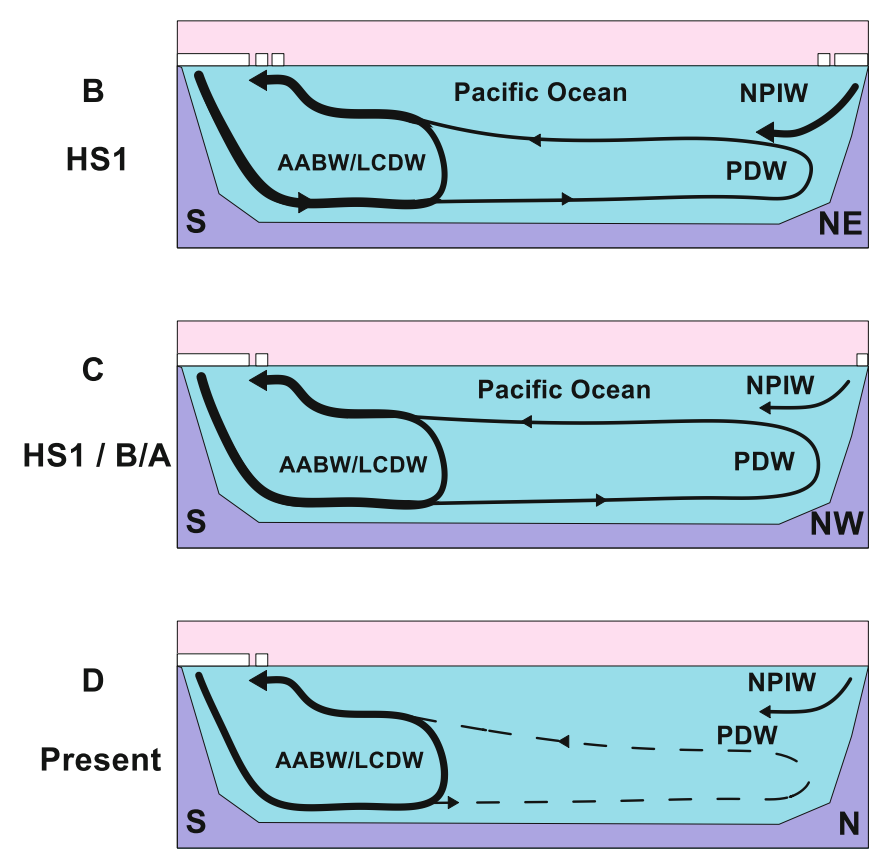

Fig. 7. The schemes of the AABW formation and PDW ventilation over the last glacial-Holocene. A) LGM. CDW upwelling was very weak as well due to strong sea ice conditions; the ventilation of the deep water in the North Pacific was also very weak and probably was provided by AMOC. B) HS1. Since onset of HS1 amelioration of the sea ice and environmental condition in the Southern Ocean led to significantly increase of CDW upwelling and AABW formation with its continuously extension up to NE Pacific. C) Boundary HS1-B/A warming. Forced by culminated warming of the Antarctica and Southern Ocean and decreasing of water column weight above the DPW due to renewal of the surface water stratification in the North Pacific, the AABW move up to NW Pacific and ventilation of the PDW in NER area. D) Modern. The AABW formation and its extension was mostly confined by the Southern Hemisphere, while deep water in the North pacific was weakly ventilated by mixed North Atlantic and Southern Ocean waters.

along the eastern edge of the NER (Fig. 6). Penetration of southern water into the NE Pacific, due to eastward deviations of the western branches of the deep current at nearly $30^{\circ} \mathrm{N}$ (Owens and Warren, 2001), is in agreement with Gebhardt et al. (2008) (core MD02-2489) and Du et al. (2018) (core U14-18) (Fig. 6).

Temporal evolution of the AABW extension and North Pacific deep water ventilation over the last $20 \mathrm{ka}$ are schematically shown in Fig. 7. During the Last Glacial maximum (LGM) the ventilation of the N Pacific was very weak and probably was provided by AMOC, while CDW upwelling was very weak as well due to strong sea ice conditions (panel A). Since onset of HS1, amelioration of the sea ice and environmental condition in the Southern Ocean led to significant increasing of CDW upwelling and AABW formation with its continuously extension up to NE Pacific (panel B). Culminated warming of the Antarctica and Southern Ocean at the boundary of HS1 and B/A warming and renewal of the surface water stratification in the North Pacific promote extension of the AABW up to NW Pacific and ventilation of the PDW in NER area (panel C). According to Talley's calculation (2008) and rate of deep ocean circulation by (Matsumoto, 2007) the modern formation and extension of AABW was mostly confined by the Southern Hemisphere, 
while North Pacific waters were weakly ventilated by mixed North Atlantic and Southern Ocean waters (panel D).

\section{Conclusions}

We present records of productivity proxies $\left(\mathrm{CaCO}_{3}\right.$, opal, TOC and chlorin content), $\delta^{18} \mathrm{O}$ and $\delta^{13} \mathrm{C}$ of $\mathrm{BF}$ and $\mathrm{PF}$, and IRD content over the last $20 \mathrm{kyr}$ in six cores (three new and three previously published, all from 2300 to $3300 \mathrm{~m}$ depth) from the NER region, including the Meiji, Detroit and Tenji Seamounts. In addition, new data of redox-sensitive elemental content, and BF abundance and species composition for core MD-16 are presented. Age models for the cores were constructed using AMS ${ }^{14} \mathrm{C}$ data for $\mathrm{PF}$ and their correlation with a suite of atmospheric ${ }^{14} \mathrm{C}$ plateaus following the plateau-tuning technique for core MD- 16 . The most important feature of all cores is a sharp rise in $\mathrm{CaCO}_{3}$ content called the AICC, i.e. the entire NER region, around the onset of the B/A warming. According to ${ }^{14} \mathrm{C}$ dated sediments of core MD-16, the age of the AICC is defined as $14.5 \pm 0.2 \mathrm{ka}$. We applied this key time point to the age model of all studied cores, based on the hypothesis that environmental and hydrological changes occurred synchronously in the study area. The AICC required a large influx of relatively young, well-oxygenated water with a high carbonate ion concentration into the deep waters of the NER area. The age of the AICC (14.5 $\pm 0.2 \mathrm{ka})-$ close to the start of the B/A warming - argues against a North Atlantic origin of this water, but is consistent with an input of Southern Oceansourced waters during the culmination of Antarctic warming at the boundary of HS1 and B/A warming, accompanied by accelerated upwelling of CDW and penetration of AABW/Lower CDW into the deep water of the NER area. The $\delta^{13} \mathrm{C}$ results of benthic epifaunal and infaunal species, redox-sensitive metals, and $\mathrm{BF}$ abundance and species assemblages indicate flushing of well-oxygenated and nutrient-enriched waters into the deep water of the NER.

IRD data show that sea ice, derived mostly from the Bering Sea, significantly affected the environment and productivity in the NER region during the LGM, then decreased strongly over the early deglaciation. There was little influence of sea ice since the onset of the B/A warming. According to sea ice influence and changes in the environmental conditions of the NER area, the surface productivity as shown by TOC and chlorin proxies was low during the LGM and early HS1, increased continuously from 17.5-16 ka due to shrinking sea ice cover and amelioration of the surface environment, and reached a maximum value at the beginning of the B/A warming. The results for BF abundance and species composition, and $\delta^{13} \mathrm{C}$ offset between epifaunal and infaunal foraminifera, allow us to conclude that the primary and export productivity in the NER area during the B/A warming was high and did not change significantly, consistent with a high supply of nutrients, warm climate and low sea ice influence. A recorded decrease in the TOC and chlorin proxies during the B/A warming was likely biased by accelerated organic remineralization in sediments under higher sediment oxygenation since the AICC.

The significant decrease of sea ice influence in the NER area since the onset of the B/A warming coupled with increased silica-enriched continental runoff associated with intensification of the East Asia monsoon and with input of southern origin nutrient-enriched water was likely the main reason for the rise in the productivity of diatoms and their accumulation in NW Pacific sediments.

Supplementary data to this article can be found online at https:// doi.org/10.1016/j.gloplacha.2020.103315.

\section{Declaration of Competing Interest}

The authors declare that they have no known competing financial interests or personal relationships that could have appeared to influence the work reported in this paper.

\section{Acknowledgments}

We are grateful to Dr. Lloyd Keigwin for the opportunity to measure the $\delta^{18} \mathrm{O}$ and $\delta^{13} \mathrm{C}$ of foraminifera in core GC-36 sediments in his lab, and to Dr. John Southon for kindly measuring AMS ${ }^{14} \mathrm{C}$ data in the same core. We greatly appreciate Dr. Ellen Thomas and an anonymous reviewer for their valuable comments and editing. We thank Dr. Selvaraj Kandasamy (Xiamen University) for manuscript correction. This work was supported by the Russian Foundation for Basic Research (19-05-00663a), Ministry Education and Science of Russian Federation theme No. 7 AAAA-A17-1170301100330 of POI FEB RAS, International Taiwan-Far Eastern Branch of Russian Academy of Science grant No. 17-MHT-003, the National Natural Science Foundation of China (41876065, 41476056, 41611130042 and U1606401), National Program on Global Change and Air-Sea Interaction (grant no. GASIGEOGE-04), the International Cooperative Project in Polar Regions (201613) and Russian Science Foundation \#19-77-10030. The sediments of core LV76-18 were measured at the shared research center SSTRC on the basis of the VEPP-4-VEPP-2000 complex at BINP SB RAS, using equipment supported by project RFMEFI62119X0022. We especially appreciate useful comments given by Prof. Michael Sarnthein (University of Kiel, Germany) on the construction of the age models, providing improved correlation of AMS ${ }^{14} \mathrm{C}$ data of core MD-16 with Suigetsu atmosphere ${ }^{14} \mathrm{C}$ plateaus and sieved samples of the core MD-16 sediments for $\mathrm{BF}$ analysis.

\section{References}

Ahagon, N., Ohkushi, K., Uchida, M., Mishima, T., 2003. Mid-depth circulation in the Northwest Pacific during the last deglaciation: evidence from foraminiferal radiocarbon ages. Geophys. Res. Lett. 30, 2097. https://doi.org/10.1029/2003GL018287. Altenbach, A.V., Pflaumann, U., Schiebel, R., Thies, A., Timm, S., Trauth, M., 1999. Scaling percentages and distributional patterns of benthic foraminifera with flux rates of organic carbon. J. Foraminifer. Res. 29, 173-185.

Anderson, R.F., Ali, S., Bradtmiller, L.I., Nielsen, S.H.H., Fleisher, M.Q., Anderson, B.E., Burckle, L.H., 2009. Wind-driven upwelling in the Southern Ocean and the deglacial rise in atmospheric CO2. Science 323, 1443-1448. https://doi.org/10.1126/science. 1167441.

Bauch, D., Carstens, J., Wefer, G., 1997. Oxygen isotope composition of living Neogloboquadrina pachyderma (sin.) in the Arctic Ocean. Earth Planet. Sci. Lett. 146, 47-58. https://doi.org/10.1016/S0012-821X(96)00211-7.

Be, A.W.H., 1977. An ecological, zoogeographic and taxonomic review of recent planktonic foraminifera. In: Ramsay, A.T.S. (Ed.), Oceanic Micropaleontology. Academic Press, London, pp. 1-100.

Berger, A.L., 1978. Long-term variations of caloric insolation resulting from the earth's orbital elements. Quat. Res. 9, 139-167. https://doi.org/10.1016/0033-5894(78) 90064-9.

Berger, A.L., Loutre, M.-F., Yin, Q., 2010. Total irradiation during any time interval of the year using elliptic integrals. Quat. Sci. Rev. 29, 1968-1982. https://doi.org/10.1016/ j.quascirev.2010.05.007.

Bodin, S., Godet, A., Matera, V., Steinmann, P., Vermeulen, J., Gardin, S., Adatte, T., Coccioni, R., Föllmi, K.B., 2007. Enrichment of redox-sensitive trace metals (U, V, Mo, As) associated with the late Hauterivian Faraoni oceanic anoxic event. Int. J. Earth Sci. 96, 327-341. https://doi.org/10.1007/s00531-006-0091-9.

Bronk Ramsey, C., Staff, R.A., Bryant, C.L., Brock, F., Kitagawa, H., van der Plicht, J., Schlolaut, G., Marshall, M.H., Brauer, A., Lamb, H.F., Payne, R.L., Tarasov, P.E., Haraguchi, T., Gotanda, K., Yonenobu, H., Yokoyama, Y., Tada, R., Nakagawa, T., 2012. A complete terrestrial radiocarbon record for 11.2 to $52.8 \mathrm{kyr}$ BP. Science 338 , 370-374. https://doi.org/10.1126/science.1226660. (80).

Burke, A., Robinson, L.F., 2012. The Southern Ocean's role in carbon exchange during the last deglaciation. Science 335, 557-561. https://doi.org/10.1126/science. 1208163. (80).

Chen, C.T.A., Feely, R.A., Gendron, J.F., 1988. Lysocline, calcium carbonate compensation depth, and calcareous sediments in the North Pacific Ocean. Pac. Sci. 42, 237-252.

Conolly, J.R., Ewing, M., 1970. Ice-rafted detritus in Northwest Pacific deep-sea sediments. In: Hays, J.D. (Ed.), Geological Investigations of the North Pacific. Geological Society of America, Boulder, Colorado, pp. 219-231.

Crusius, J., Pedersen, T.F., Kienast, S., Keigwin, L., Labeyrie, L., 2004. Influence of Northwest Pacific productivity on North Pacific intermediate water oxygen concentrations during the Bølling-Ållerød interval (14.7-12.9 ka). Geology 32, 633-636. https://doi.org/10.1130/G20508.1.

Cuffey, K.M., Clow, G.D., Steig, E.J., Buizert, C., Fudge, T.J., Koutnik, M., Waddington, E.D., Alley, R.B., Severinghaus, J.P., 2016. Deglacial temperature history of West Antarctica. Proc. Natl. Acad. Sci. 113, 14249-14254. https://doi.org/10.1073/pnas. 1609132113.

Du, J., Haley, B.A., Mix, A.C., Walczak, M.H., Praetorius, S.K., 2018. Flushing of the deep 
Pacific Ocean and the deglacial rise of atmospheric $\mathrm{CO} 2$ concentrations. Nat. Geosci. 11, 749-755. https://doi.org/10.1038/s41561-018-0205-6.

Emile-Geay, J., Cane, M.A., Naik, N., Seager, R., Clement, A.C., van Geen, A., 2003. Warren revisited: Atmospheric freshwater fluxes and "Why is no deep water formed in the North Pacific". J. Geophys. Res. 108, 3178. https://doi.org/10.1029/ 2001JC001058.

EPICA Community Members, 2006. One-to-one coupling of glacial climate variability in Greenland and Antarctica. Nature 444, 195-198. https://doi.org/10.1038/ nature 05301.

Favorite, F., Dodimead, A.J.J., Nasu, K., 1976. Oceanography of the Subarctic Pacific Region, 1960-71. International North Pacific Fisheries Commission p. 187.

Galbraith, E.D., Jaccard, S.L., Pedersen, T.F., Sigman, D.M., Haug, G.H., Cook, M., Southon, J.R., Francois, R., 2007. Carbon dioxide release from the North Pacific abyss during the last deglaciation. Nature 449, 890-893. https://doi.org/10.1038/ nature06227.

Gebhardt, H., Sarnthein, M., Grootes, P.M., Kiefer, T., Kuehn, H., Schmieder, F., Röhl, U., 2008. Paleonutrient and productivity records from the subarctic North Pacific for Pleistocene glacial terminations I to V. Paleoceanography 23, 1-21. https://doi.org/ 10.1029/2007PA001513.

Gong, X., Lembke-Jene, L., Lohmann, G., Knorr, G., Tiedemann, R., Zou, J.J., Shi, X.F. 2019. Enhanced North Pacific deep-ocean stratification by stronger intermediate water formation during Heinrich Stadial 1. Nat. Commun. 10, 656. https://doi.org/ 10.1038/s41467-019-08606-2.

Gooday, A.J., 1988. A response by benthic Foraminifera to the deposition of phytodetritus in the deep sea. Nature 332, 70-73. https://doi.org/10.1038/332070a0.

Gooday, A.J., 2003. Benthic foraminifera (protista) as tools in deep-water palaeoceanography: environmental influences on faunal characteristics. Adv. Mar. Biol. 1-90. https://doi.org/10.1016/S0065-2881(03)46002-1.

Gorbarenko, S.A., 1996. Stable isotope and lithologic evidence of late-glacial and holocene oceanography of the Northwestern Pacific and its marginal seas. Quat. Res. 46, 230-250. https://doi.org/10.1006/qres.1996.0063.

Gorbarenko, S., Southon, J., Keigwin, L., Cherepanova, M., Gvozdeva, I., 2004. Late Pleistocene-Holocene oceanographic variability in the Okhotsk Sea: geochemical, lithological and paleontological evidence. Palaeogeogr. Palaeoclimatol. Palaeoecol. 209, 281-301. https://doi.org/10.1016/j.palaeo.2004.02.013

Gorbarenko, S.A., Harada, N., Malakhov, M.I., Vasilenko, Y.P., Bosin, A.A., Goldberg, E.L., 2010. Orbital and millennial-scale environmental and sedimentological changes in the Okhotsk Sea during the last 350kyr. Glob. Planet. Chang. 72, 79-85. https:// doi.org/10.1016/j.gloplacha.2010.03.002.

Gorbarenko, S.A., Artemova, A.V., Goldberg, E.L., Vasilenko, Y.P., 2014. The response of the Okhotsk Sea environment to the orbital-millennium global climate changes during the last glacial maximum, deglaciation and Holocene. Glob. Planet. Chang. 116, 76-90. https://doi.org/10.1016/j.gloplacha.2014.02.002.

Gray, W.R., Rae, J.W.B., Wills, R.C.J., Shevenell, A.E., Taylor, B., Burke, A., Foster, G.L., Lear, C.H., 2018. Deglacial upwelling, productivity and CO2 outgassing in the North Pacific Ocean. Nat. Geosci. 11, 340-344. https://doi.org/10.1038/s41561-018 0108-6.

Gustafsson, M., Nordberg, K., 2001. Living (stained) benthic foraminiferal response to primary production and hydrography in the deepest part of the Gullmar Fjord, Swedish west coast, with comparisons to Hoglund's 1927 material. J. Foraminifer. Res. 31, 2-11. https://doi.org/10.2113/0310002.

Harris, P.G., Zhao, M., Rosell-Melé, A., Tiedemann, R., Sarnthein, M., Maxwell, J.R., 1996. Chlorin accumulation rate as a proxy for Quaternary marine primary productivity. Nature 383, 63-65. https://doi.org/10.1038/383063a0.

Hendy, I.L., Kennett, J.P., Roark, E.B., Ingram, B.L., 2002. Apparent synchroneity of submillennial scale climate events between Greenland and Santa Barbara Basin, California from 30-10 ka. Quat. Sci. Rev. 21, 1167-1184. https://doi.org/10.1016/ S0277-3791(01)00138-X.

Hollister, C.D., Nowell, A.R.M., Jumars, P.A., 1984. The dynamic abyss. Sci. Am. 250, $42-53$.

Hoogakker, B.A.A., Elderfield, H., Schmiedl, G., McCave, I.N., Rickaby, R.E.M., 2015 Glacial-interglacial changes in bottom-water oxygen content on the Portuguese margin. Nat. Geosci. 8, 40-43. https://doi.org/10.1038/ngeo2317.

Jaccard, S.L., Galbraith, E.D., 2013. Direct ventilation of the North Pacific did not reach the deep ocean during the last deglaciation. Geophys. Res. Lett. 40, 199-203. https:// doi.org/10.1029/2012GL054118.

Jaccard, S.L., Haug, G.H., Sigman, D.M., Pedersen, T.F., Thierstein, H.R., Röhl, U., 2005. Glacial/interglacial changes in subarctic north pacific stratification. Science 308 , 1003-1006. https://doi.org/10.1126/science.1108696.

Jaccard, S.L., Galbraith, E.D., Sigman, D.M., Haug, G.H., 2010. A pervasive link between Antarctic ice core and subarctic Pacific sediment records over the past 800 kyrs. Quat. Sci. Rev. 29, 206-212. https://doi.org/10.1016/j.quascirev.2009.10.007.

Jansen, M.F., Nadeau, L.-P., 2016. The effect of Southern Ocean surface buoyancy loss on the deep-ocean circulation and stratification. J. Phys. Oceanogr. 46, 3455-3470. https://doi.org/10.1175/JPO-D-16-0084.1.

Jorissen, F.J., Fontanier, C., Thomas, E., 2007. Chapter seven paleoceanographical proxies based on deep-sea benthic foraminiferal assemblage characteristics. Dev. Mar. Geol. https://doi.org/10.1016/S1572-5480(07)01012-3.

Keigwin, L.D., 1998. Glacial-age hydrography of the far Northwest Pacific Ocean. Paleoceanography 13, 323-339. https://doi.org/10.1029/98PA00874.

Keigwin, L.D., Jones, G.A., Froelich, P.N., 1992. A 15,000 year paleoenvironmental record from Meiji Seamount, far northwestern Pacific. Earth Planet. Sci. Lett. 111, 425-440. https://doi.org/10.1016/0012-821X(92)90194-Z.

Key, R.M., Kozyr, A., Sabine, C.L., Lee, K., Wanninkhof, R., Bullister, J.L., Feely, R.A., Millero, F.J., Mordy, C., Peng, T.-H., 2004. A global ocean carbon climatology: results from Global Data Analysis Project (GLODAP). Glob. Biogeochem. Cycles 18. https://
doi.org/10.1029/2004GB002247.

Kiefer, T., Sarnthein, M., Erlenkeuser, H., Grootes, P.M., Roberts, A.P., 2001. North Pacific response to millennial-scale changes in ocean circulation over the last $60 \mathrm{kyr}$ Paleoceanography 16, 179-189. https://doi.org/10.1029/2000PA000545.

Kohfeld, K.E., Chase, Z., 2011. Controls on deglacial changes in biogenic fluxes in the North Pacific Ocean. Quat. Sci. Rev. 30, 3350-3363. https://doi.org/10.1016/j. quascirev.2011.08.007.

Kroopnick, P.M., 1985. The distribution of $13 \mathrm{C}$ of $\Sigma \mathrm{CO} 2$ in the world oceans. Deep Sea Res. 32, 57-84. https://doi.org/10.1016/0198-0149(85)90017-2.

Lyakhin, Y.I., 1968. Calcium carbonate saturation of Pacific water. Oceanology 8, 44-53.

Mackensen, A., Schmiedl, G., Harloff, J., Giese, M., 1995. Deep-sea foraminifera in the South Atlantic Ocean: ecology and assemblage generation. Micropaleontology 41, 342. https://doi.org/10.2307/1485808.

Mammerickx, J., 1985. A deep-sea thermohaline flow path in the Northwest Pacific. Mar. Geol. 65, 1-19. https://doi.org/10.1016/0025-3227(85)90043-X.

Marchitto, T.M., Lehman, S.J., Ortiz, J.D., Fluckiger, J., van Geen, A., Flückiger, J., van Geen, A., 2007. Marine radiocarbon evidence for the mechanism of deglacial atmospheric CO2 rise. Science 316, 1456-1459. https://doi.org/10.1126/science. 1138679. (80)

Marshall, J., Speer, K., 2012. Closure of the meridional overturning circulation through Southern Ocean upwelling. Nat. Geosci. 5, 171-180. https://doi.org/10.1038/ ngeo1391.

Matsumoto, K., 2007. Radiocarbon-based circulation age of the world oceans. J. Geophys Res. Ocean. 112, 1-7. https://doi.org/10.1029/2007JC004095.

Max, L., Riethdorf, J.R., Tiedemann, R., Smirnova, M., Lembke-Jene, L., Fahl, K., Nrnberg, D., Matul, A., Mollenhauer, G., 2012. Sea surface temperature variability and sea-ice extent in the subarctic Northwest Pacific during the past 15,000 years. Paleoceanography 27, 1-20. https://doi.org/10.1029/2012PA002292.

Max, L., Lembke-Jene, L., Riethdorf, J.-R., Tiedemann, R., Nürnberg, D., Kühn, H., Mackensen, A., 2014. Pulses of enhanced North Pacific intermediate water ventilation from the Okhotsk Sea and Bering Sea during the last deglaciation. Clim. Past 10 591-605. https://doi.org/10.5194/cp-10-591-2014.

McManus, J.F., Bond, G.C., Broecker, W.S., Johnsen, S.J., Labeyrie, L.D., Higgins, S.M., 1994. High-resolution climate records from the North Atlantic during the last interglacial. Nature 371, 326-329. https://doi.org/10.1038/371326a0.

McManus, J.F., Francois, R., Gherardi, J.-M., Keigwin, L.D., Brown-Leger, S., 2004. Collapse and rapid resumption of Atlantic meridional circulation linked to deglacial climate changes. Nature 428, 834-837. https://doi.org/10.1038/nature02494.

Monnin, E., Indermühle, A., Dällenbach, A., Flückiger, J., Stauffer, B., Stocker, T.F., Raynaud, D., Barnola, J.-M., 2001. Atmospheric CO2 concentrations over the last glacial termination. Science 291, 112-114. https://doi.org/10.1126/science.291. 5501.112.

Morford, J.L., Emerson, S., 1999. The geochemistry of redox sensitive trace metals in sediments. Geochim. Cosmochim. Acta 63, 1735-1750. https://doi.org/10.1016/ S0016-7037(99)00126-X.

Mortlock, R.A., Froelich, P.N., 1989. A simple method for the rapid determination of biogenic opal in pelagic marine sediments. Deep Sea Res. 36, 1415-1426. https://doi org/10.1016/0198-0149(89)90092-7.

Ohkushi, K., Thomas, E., Kawahata, H., 2000. Abyssal benthic foraminifera from the northwestern Pacific (Shatsky Rise) during the last 298 kyr. Mar. Micropaleontol. 38 119-147. https://doi.org/10.1016/S0377-8398(99)00040-7.

Ohkushi, K., Hata, M., Nemoto, N., 2018. Response of deep-sea benthic foraminifera to paleoproductivity changes on the Shatsky Rise in the Northwestern Pacific Ocean over the last 187 Kyr. Paleontol. Res. 22, 326-351. https://doi.org/10.2517/ 2017 PR027.

Okazaki, Y., Timmermann, A., Menviel, L., Harada, N., Abe-Ouchi, A., Chikamoto, M.O., Mouchet, A., Asahi, H., 2010. Deepwater formation in the North Pacific during the last glacial termination. Science 329, 200-204. https://doi.org/10.1126/science. 1190612. (80).

Okazaki, Y., Sagawa, T., Asahi, H., Horikawa, K., Onodera, J., 2012. Ventilation changes in the western North Pacific since the last glacial period. Clim. Past 8, 17-24. https:// doi.org/10.5194/cp-8-17-2012.

Owens, W.B., Warren, B.A., 2001. Deep circulation in the northwest corner of the Pacific Ocean. Deep Sea Res. 48, 959-993. https://doi.org/10.1016/S0967-0637(00) 00076-5.

Parrenin, F., Masson-Delmotte, V., Kohler, P., Raynaud, D., Paillard, D., Schwander, J., Barbante, C., Landais, A., Wegner, A., Jouzel, J., 2013. Synchronous change of atmospheric $\mathrm{CO} 2$ and antarctic temperature during the last deglacial warming. Science 339, 1060-1063. https://doi.org/10.1126/science.1226368.

Piminov, P.A., Baranov, G.N., Bogomyagkov, A.V., Berkaev, D.E., Borin, V.M., Dorokhov, V.L., Karnaev, S.E., Kiselev, V.A., Levichev, E.B., Meshkov, O.I., Mishnev, S.I., Nikitin, S.A., Nikolaev, I.B., Sinyatkin, S.V., Vobly, P.D., Zolotarev, K.V., Zhuravlev, A.N., 2016. Synchrotron radiation research and application at VEPP-4. Phys. Procedia 84 19-26. https://doi.org/10.1016/j.phpro.2016.11.005.

Polyak, L., Best, K.M., Crawford, K.A., Council, E.A., St-Onge, G., 2013. Quaternary history of sea ice in the western Arctic Ocean based on foraminifera. Quat. Sci. Rev. 79, 145-156. https://doi.org/10.1016/j.quascirev.2012.12.018.

Psheneva, O.Y., Gorbarenko, S.A., 2017. The responses of benthic foraminifera to paleoceanographic changes during the last glacial maximum, deglaciation, and the Holocene in the northwestern Pacific. Russ. J. Mar. Biol. 43. https://doi.org/10. 1134/S1063074017010102.

Rea, D.K., 1995. Scientific results of drilling the North Pacific transect. Proc. Ocean Drill. Program Sci. Results 145, 577-596.

Reid, J.L., 1969. Preliminary results of measurements of deep currents in the Pacific Ocean. Nature 221, 848.

Reynolds, R.W., Rayner, N.A., Smith, T.M., Stokes, D.C., Wang, W., 2002. An improved in 
situ and satellite SST analysis for climate. J. Clim. 15, 1609-1625. https://doi.org/ 10.1175/1520-0442(2002)015 < 1609:AIISAS > 2.0.CO;2.

Riethdorf, J.-R., Nürnberg, D., Max, L., Tiedemann, R., Gorbarenko, S.A., Malakhov, M.I., 2013. Millennial-scale variability of marine productivity and terrigenous matter supply in the western Bering Sea over the past 180 kyr. Clim. Past 9, 1345-1373. https://doi.org/10.5194/cp-9-1345-2013.

Sarnthein, M., Grootes, P.M., Kennett, J.P., Nadeau, M.-J., 2007. 14C reservoir ages show deglacial changes in ocean currents and carbon cycle. In: Ocean Circulation: Mechanisms and Impacts-Past and Future Changes of Meridional Overturning, pp. 175-196. https://doi.org/10.1029/173GM13.

Sarnthein, M., Balmer, S., Grootes, P.M., Mudelsee, M., 2015. Planktic and benthic $14 \mathrm{C}$ reservoir ages for three ocean basins, calibrated by a suite of $14 \mathrm{C}$ plateaus in the glacial-to-deglacial suigetsu atmospheric 14 C record. Radiocarbon 57, 129-151. https://doi.org/10.2458/azu_rc.57.17916.

Schlolaut, G., 2018. The varve interpolation program 3.0.0 - a unique and easy to use tool for incompletely varved sediments. Quat. Geochronol. 48, 17-24. https://doi.org/10. 1016/j.quageo.2018.07.014.

Schlosser, P., Bullister, J.L., Fine, R., Jenkins, W.J., Key, R., Lupton, J., Roether, W., Smethie, W.M., 2001. Transformation and age of water masses. In: Ocean Circulation and Climate: Observing and Modelling the Global Ocean, pp. 431-452. https://doi. org/10.1016/S0074-6142(01)80133-9.

Schmiedl, G., Mackensen, A., Müller, P.J., 1997. Recent benthic foraminifera from the eastern South Atlantic Ocean: dependence on food supply and water masses. Mar. Micropaleontol. 32, 249-287. https://doi.org/10.1016/S0377-8398(97)00023-6.

Schmitz, W.J., 1995. On the interbasin-scale thermohaline circulation. Rev. Geophys. 33, 151. https://doi.org/10.1029/95RG00879.

Seki, O., Ikehara, M., Kawamura, K., Nakatsuka, T., Ohnishi, K., Wakatsuchi, M., Narita, H., Sakamoto, T., 2004. Reconstruction of paleoproductivity in the Sea of Okhotsk over the last 30 kyr. Paleoceanography 19. https://doi.org/10.1029/2002PA000808.

Shakun, J.D., Clark, P.U., He, F., Marcott, S.A., Mix, A.C., Liu, Z., Otto-Bliesner, B., Schmittner, A., Bard, E., 2012. Global warming preceded by increasing carbon dioxide concentrations during the last deglaciation. Nature 484, 49-54. https://doi. org/10.1038/nature10915.

Shcherbina, A.Y., Talley, L.D., Rudnick, D.L., 2003. Direct observations of North Pacific ventilation: brine rejection in the Okhotsk Sea. Science 302, 1952-1955. https://doi. org/10.1126/science.1088692.

Sigman, D.M., Boyle, E.A., 2000. Glacial/interglacial variations in atmospheric carbon dioxide. Nature 407, 859-869. https://doi.org/10.1038/35038000.

Sigman, D.M., Hain, M.P., Haug, G.H., 2010. The polar ocean and glacial cycles in atmospheric CO2 concentration. Nature 466, 47-55. https://doi.org/10.1038/ nature09149.

Simstich, J., Sarnthein, M., Erlenkeuser, H., 2003. Paired $\delta 180$ signals of Neogloboquadrina pachyderma(s) and Turborotalita quinqueloba show thermal stratification structure in Nordic Seas. Mar. Micropaleontol. 48, 107-125. https:// doi.org/10.1016/S0377-8398(02)00165-2.

Skinner, L.C., Fallon, S., Waelbroeck, C., Michel, E., Barker, S., 2010. Ventilation of the deep Southern Ocean and deglacial CO2 rise. Science 328, 1147-1151. https://doi. org/10.1126/science.1183627. (80).

Smart, C.W., Thomas, E., Bracher, C.M., 2019. Holocene variations in North Atlantic export productivity as reflected in bathyal benthic foraminifera. Mar. Micropaleontol. 149, 1-18. https://doi.org/10.1016/j.marmicro.2019.03.004.

St. John, K.E.K., Krissek, L.a., 1999. Regional patterns of Pleistocene ice-rafted debris flux in the North Pacific. Paleoceanography 14, 653-662. https://doi.org/10.1029/ 1999PA900030.

Stuiver, M., Reimer, P.J., 1993. Extended 14C data base and revised calib 3.0 14C age calibration program. Radiocarbon 35, 215-230.

Takata, H., Kim, H.J., Asahi, H., Thomas, E., Yoo, C.M., Chi, S.B., Khim, B.-K., 2019. Central Equatorial Pacific benthic foraminifera during the mid-Brunhes dissolution interval: ballasting of particulate organic matter by biogenic silica and carbonate. Quat. Sci. Rev. 210, 64-79. https://doi.org/10.1016/j.quascirev.2019.02.030.

Talley, L.D., 1993. Distribution and formation of North Pacific intermediate water. J. Phys. Oceanogr. 23, 517-537. https://doi.org/10.1175/1520-0485(1993) $023<0517$ :DAFONP > 2.0.CO; 2 .

Talley, L.D., 2003. Shallow, intermediate, and deep overturning components of the global heat budget. J. Phys. Oceanogr. 33, 530-560. https://doi.org/10.1175/15200485(2003)033<0530:SIADOC > 2.0.CO;2.

Thomas, E., Booth, L., Maslin, M., Shackleton, N.J., 1995. Northeastern Atlantic benthic foraminifera during the last 45,000 years: changes in productivity seen from the bottom up. Paleoceanography 10, 545-562. https://doi.org/10.1029/94PA03056.

Tomczak, M., Godfrey, J.S., 1994. Regional Oceanography. Elsevierhttps://doi.org/10 1016/C2009-0-14825-0.

VanLaningham, S., Pisias, N.G., Duncan, R.A., Clift, P.D., 2009. Glacial-interglacial sediment transport to the Meiji Drift, Northwest Pacific Ocean: evidence for timing of Beringian outwashing. Earth Planet. Sci. Lett. 277, 64-72. https://doi.org/10.1016/j. eps1.2008.09.033.

Velivetskaya, T.A., Ignatiev, A.V., Gorbarenko, S.A., 2009. Carbon and oxygen isotope microanalysis of carbonate. Rapid Commun. Mass Spectrom. 23, 2391-2397. https:// doi.org/10.1002/rcm.3989.

WAIS Divide Project Members, 2013. Onset of deglacial warming in West Antarctica driven by local orbital forcing. Nature 500, 440-444. https://doi.org/10.1038/ nature12376.

Wang, Y., Cheng, H., Edwards, R.L., Kong, X., Shao, X., Chen, S., Wu, J., Jiang, X., Wang, X., An, Z., 2008. Millennial- and orbital-scale changes in the East Asian monsoon over the past 224,000 years. Nature 451, 1090-1093. https://doi.org/10.1038/ nature 06692.

Warren, B.A., 1983. Why is no deep water formed in the North Pacific? J. Mar. Res. 41, 327-347. https://doi.org/10.1357/002224083788520207.

Wollenburg, J.E., Mackensen, A., 1998. Living benthic foraminifers from the Central Arctic Ocean: faunal composition, standing stock and diversity. Mar. Micropaleontol. 34, 153-185. https://doi.org/10.1016/S0377-8398(98)00007-3.

Zakharkov, S.P., Gorbarenko, S.A., Bosin, A.A., 2007. Chlorin content in sea sediments as an indication of sea primary productivity (in Russian). Bull. Far East. Branch Russ. Acad. Sci. 1, 52-58. 